\title{
Novel Wnt Regulator NEL-Like Molecule-1 Antagonizes Adipogenesis and Augments Osteogenesis Induced by Bone Morphogenetic Protein 2
}

Jia Shen, ${ }^{* \dagger}$ Aaron W. James, ${ }^{* \dagger}$ Xinli Zhang, ${ }^{* \dagger}$ Shen Pang, ${ }^{\dagger}$ Janette N. Zara, ${ }^{* \dagger}$ Greg Asatrian, ${ }^{*}$ Michael Chiang, ${ }^{*}$ Min Lee, Kevork Khadarian, ${ }^{\dagger}$ Alan Nguyen, ${ }^{*}$ Kevin S. Lee, ${ }^{*}$ Ronald K. Siu, ${ }^{*}$ Sotirios Tetradis, ${ }^{\oplus}$ Kang Ting, ${ }^{*}$ and Chia Soo ${ }^{\dagger}$

From the Divisions of Growth and Development and Section of Orthodontics, ${ }^{*}$ Advanced Prosthodontics, ${ }^{\S}$ and Diagnostic and Surgical Sciences, ${ }^{\circledR}$ UCLA School of Dentistry, the UCLA Division of Plastic and Reconstructive Surgery, ${ }^{\dagger}$ Department of Orthopaedic Surgery and Orthopaedic Hospital Research Center at UCLA, and the Department of Pathology and Laboratory Medicine ${ }^{\ddagger}$ David Geffen School of Medicine at UCLA, University of California, Los Angeles, Los Angeles, California

\author{
Accepted for publication \\ October 16, 2015. \\ Address correspondence to Kang Ting, \\ D.M.D., UCLA School of Dentistry, \\ University of California, Los Angeles, \\ Box 951668, CHS 30-113, Los \\ Angeles, CA 90095-1668; or Chia Soo, \\ M.D., (Correspondent for the Editorial \\ and Production offices), UCLA Divi- \\ sion of Plastic and Reconstructive \\ Surgery and Department of Orthopae- \\ dic Surgery and the Orthopaedic \\ Hospital Research Center, University \\ of California, Los Angeles, Los \\ Angeles, CA 90095-1579. \\ E-mail: kting@dentistry.ucla.edu or \\ bsoo@ucla.edu.
}

\begin{abstract}
The differentiation factor NEL-like molecule-1 (NELL-1) has been reported as osteoinductive in multiple in vivo preclinical models. Bone morphogenetic protein (BMP)-2 is used clinically for skeletal repair, but in vivo administration can induce abnormal, adipose-filled, poorquality bone. We demonstrate that NELL-1 combined with BMP2 significantly optimizes osteogenesis in a rodent femoral segmental defect model by minimizing the formation of BMP2-induced adipose-filled cystlike bone. In vitro studies using the mouse bone marrow stromal cell line M2-10B4 and human primary bone marrow stromal cells have confirmed that NELL-1 enhances BMP2-induced osteogenesis and inhibits BMP2-induced adipogenesis. Importantly, the ability of NELL-1 to direct BMP2-treated cells toward osteogenesis and away from adipogenesis requires intact canonical Wnt signaling. Overall, these studies establish the feasibility of combining NELL-1 with BMP2 to improve clinical bone regeneration and provide mechanistic insight into canonical Wnt pathway activity during NELL-1 and BMP2 osteogenesis. The novel abilities of NELL-1 to stimulate Wnt signaling and to repress adipogenesis may highlight new treatment approaches for bone loss in osteoporosis. (Am J Pathol 2016, 186: 419-434; http://dx.doi.org/10.1016/j.ajpath.2015.10.011)
\end{abstract}

NEL-like molecule-1 (NELL-1) is an osteoinductive growth factor first identified through its overexpression in pathologically fusing suture specimens from patients with craniosynostosis. ${ }^{1,2}$ Transgenic Nell1-overexpressing mice recapitulate craniosynostosis-like phenotypes, exhibiting gross calvarial bone overgrowth and increased osteoblast differentiation. ${ }^{3}$ Conversely, Nell1 deficiency severely disrupts bone growth, as mice with nonsense mutations in Nelll die perinatally with major skeletal anomalies in the craniofacial complex, spine, and long bones. ${ }^{4-6}$ Highlighting the central role of NELL-1 in skeletal development, NELL-1 mediates key downstream effects of the master osteogenic regulator runt-related transcription factor $2(\mathrm{RUNX} 2)^{7}$ and can partially rescue $R U N X 2$ loss of function. ${ }^{8}$ NELL-1 can also transiently activate mitogen-activated protein kinase signaling to induce RUNX2 phosphorylation and osteogenic differentiation. ${ }^{9}$ Recently, we

\footnotetext{
Supported by the California Institute for Regenerative Medicine Early Translational II Research Award TR2-01821 (C.S.); NIH/NIDCR grants R21 DE0177711 (C.S.), RO1 DE01607 (K.T.), and RO1 AR061399-01A1 (C.S.); University of California Discovery grant 07-10677 (C.S.); Eli \& Edythe Broad Center of Regenerative Medicine; and a Stem Cell Research at UCLA Innovation Award. R.K.S. and A.W.J. were supported by T32 training fellowship 5T32DE007296-14. J.N.Z. was supported by CIRM training fellowship TG2-01169.

Disclosures: K.T. and C.S. are inventors of NELL-1-related patents and are founders of Bone Biologics Inc., which sublicenses NELL-1 patents from the UC Regents.
} 
demonstrated that osteoinductive effects of NELL-1 are partially mediated through binding to the intracellular molecule apoptosis related protein 3 and integrin- $\beta_{1} \cdot{ }^{10}$ In translational models of bone repair, exogenous NELL-1 induces potent osseous healing of critical-sized rat calvarial defects, ${ }^{11}$ repair of rat femoral segmental defects (FSDs), ${ }^{12}$ as well as successful spinal fusion in rats ${ }^{13,14}$ and sheep. ${ }^{15}$ Based on these results demonstrating reproducible preclinical osteoinductivity in multiple small and large animal models, NELL-1 is being developed for therapeutic use in spinal fusion in humans.

Bone morphogenetic protein-2 (BMP2) is a U.S. Food and Drug Administration (FDA)-approved osteoinductive growth factor most commonly used for spinal fusions and treatment of skeletal defects. ${ }^{16,17}$ Notably, BMP2 has species-specific dosing responses in which the required BMP2 concentration for osteogenesis increases with phylogenetic complexity. ${ }^{18}$ The BMP2 concentration for consistent bone formation in nonhuman primates is 0.75 to $2.0 \mathrm{mg} / \mathrm{mL}$, but in rodents is only 0.02 to $0.4 \mathrm{mg} / \mathrm{mL} .^{19}$ Based on data from nonhuman primates, the minimum effective human BMP2 concentration was initially set at 1.5 $\mathrm{mg} / \mathrm{mL}$ (total dose, 4.2 to $12 \mathrm{mg}$ ) in pilot and pivotal trials in humans and is currently the approved concentration for clinical use. ${ }^{19-21}$ Unfortunately, the high BMP2 concentrations required for osteogenesis in humans are associated with significant adverse effects, including an FDA warning of life-threatening cervical swelling, ${ }^{22}$ ectopic bone formation (U.S. Food and Drug Administration, http://www.fda. gov/MedicalDevices/Safety/AlertsandNotices/PublicHealth Notifications/ucm062000.htm, last accessed September 28, 2011), ${ }^{23}$ osteoclastogenesis, ${ }^{24}$ and inconsistent bone formation. ${ }^{25}$ Thus, improving the safety and efficacy of BMP2based skeletal repair is crucial. Although NELL-1 is being developed as a standalone osteoinductive therapeutic, we previously performed studies of NELL-1 and BMP2 in animals in an effort to better understand the molecular and cellular bases of NELL-1 and/or BMP2 osteoinductivity. ${ }^{26}$ Intriguingly, we found that NELL-1 synergistically increases bone formation with BMP2 through, in part, inhibition of BMP2-induced adipogenesis, ${ }^{26}$ a well-described phenomenon documented in several in vitro and in vivo models. ${ }^{11,27,28}$

Canonical ( $\beta$-catenin-dependent) Wnt signaling regulates mesenchymal stem cell maintenance and differentiation during bone development and homeostasis. ${ }^{29-32}$ Generally, increased Wnt signaling promotes osteogenesis over adipogenesis. ${ }^{33}$ In mice, targeted disruption of Axin2, a negative regulator of Wnt signaling, ${ }^{34}$ induces craniosynostosis-like skull malformations, ${ }^{35}$ a phenotype similar to that in Nell1-overexpressing mice. ${ }^{3}$ Because canonical Wnt is a major signal transduction pathway that regulates mesenchymal stem cell commitment to osteogenic over adipogenic lineages, we examined whether NELL-1 may synergize with BMP2 in bone formation through $\beta$-catenin-dependent Wnt signaling. Here we show NELL-1 activation of canonical
Wnt signaling as a mechanistic basis for the observed NELL-1 inhibition of BMP2-induced adipogenesis and for NELL-1+BMP2 synergy in bone formation. Importantly, we establish NELL-1 as a novel Wnt pathway activator that can be applied, with BMP2 to improving the safety and efficacy of currently available boneregeneration therapies. Overall, treatment with NELL$1+$ BMP2 forms bone of better quality than that formed with either NELL-1 or BMP2 alone.

\section{Materials and Methods}

\section{Antibodies and Reagents}

Human recombinant NELL-1 was purified by Aragen Bioscience (Morgan Hill, CA). Human BMP2 (Infuse Bone Graft) was purchased from Medtronic (Minneapolis, MN). Primary antibodies used in this study were anti-Runx2 (sc-10758; Santa Cruz Biotechnology, Santa Cruz, CA), antiperoxisome proliferator-activated receptor $\gamma(\operatorname{PPAR} \gamma$; sc-7273; Santa Cruz Biotechnology), anti-CCAAT enhancer-binding protein $\alpha(\mathrm{C} / \mathrm{EBP} \alpha)$ (ab63486-100; Abcam, Cambridge, MA), antiosteocalcin (sc-18322; Santa Cruz Biotechnology), anti- $\beta$-catenin (610153; BD Biosciences, Franklin Lakes, NJ), anti-active $\beta$-catenin (05-665; Millipore, Billerica, MA) and anti- $\beta$-actin (sc-1616; Santa Cruz Biotechnology). Recombinant mouse Wnt-3a protein (1324-WN-002) and Dickkopf-related protein 1 (Dkk1) (5897-DK-010) were purchased from R\&D Systems (Minneapolis, MN). XAV939 was purchased from Cayman Chemical (Ann Arbor, MI).

\section{Implant Material}

Cylindrical poly(lactic-co-glycolic acid) (PLGA) scaffold implants were fabricated as described previously. ${ }^{12,36}$ Briefly, 85/15 D,L-PLGA (inherent viscosity, $0.61 \mathrm{dL} / \mathrm{g}$; Absorbable Polymers, Pelham, AL)/chloroform solutions were mixed with 200 to $300 \mu \mathrm{m}$-diameter sucrose to obtain $94 \%$ porosity and were compressed in a polytetrafluoroethylene mold to form scaffolds measuring $6 \mathrm{~mm}$ in length and $4 \mathrm{~mm}$ in diameter. After freeze-drying overnight, scaffolds were immersed in three changes of distilled deionized water $\left(\mathrm{ddH}_{2} \mathrm{O}\right)$ to dissolve the sucrose. All scaffolds were disinfected by immersion in $70 \%$ ethanol for 30 minutes, followed by three rinses with $\mathrm{ddH}_{2} \mathrm{O}$.

Scaffolds were then coated with hydroxyapatite to ensure efficient NELL-1 and BMP2 loading and to enhance overall osteoconductivity of the hydrophobic PLGA scaffold. Briefly, two sterile, supersaturated solutions containing ion concentrations fivefold greater than those in human plasma [simulated body fluid (SBF) 1 and 2] were sequentially applied to the scaffolds. The ionic concentrations and preparation of SBF 1 and SBF 2 were previously published. ${ }^{36}$ Immediately before the coating process, dried PLGA scaffolds were subjected to glow discharge argon 
plasma etching (Harrick Scientific, Ossining, NY) to improve wetting and coating uniformity. Etched PLGA scaffolds were then incubated in SBF 1 for 12 hours and changed to SBF 2 for another 12 hours at $37^{\circ} \mathrm{C}$ inside of a water-jacketed incubator. Coated PLGA scaffolds were rinsed gently with sterile $\mathrm{ddH}_{2} \mathrm{O}$ to wash away excess sodium chloride solution and were dried in the laminar flow hood. The thickness of the hydroxyapatite coating was 40 to $100 \mathrm{~nm}$. Apatite-coated PLGA scaffolds did not exhibit a reduction in porosity and maintained the same pore interconnectivity and pore size ranging between 200 and $300 \mu \mathrm{m}$.

Before implantation, scaffolds were impregnated with recombinant human BMP2 and/or recombinant human NELL-1. Doses of each growth factor (Table 1) were chosen based on the ability of BMP2 to consistently induce adipocytic bone cysts ${ }^{12}$ and NELL-1 to significantly improve bone regeneration in an FSD model in our previous studies. ${ }^{37}$ Each growth factor was diluted to the appropriate concentration in phosphate-buffered saline (PBS), added dropwise uniformly to the scaffolds for 20 minutes, and lyophilized in a freeze-drier overnight at $-20^{\circ} \mathrm{C}$. Implants for PBS controls were generated in the same way, except that no growth factors were added.

\section{Femoral Segmental Defect Animal Model}

All animal procedures were conducted in accordance with the Guide for the Care and Use of Laboratory Animals of the University of California (Los Angeles, CA) were and approved by the Chancellor's Animal Research Committee. Twenty-seven male Lewis rats, aged 3 months, were purchased from Taconic Farms (Hudson, NY) and assigned to experimental groups as shown in Table 1. The FSD model was performed as previously described. ${ }^{12}$ Briefly, a $25-$ to 30-mm longitudinal incision was aseptically made over the anterolateral aspect of the femur, and the overlying muscles were separated to expose the femoral shaft. For fixation, a polyethylene plate (length, $23 \mathrm{~mm}$; width, $4 \mathrm{~mm}$; height, 4 $\mathrm{mm}$ ) was placed on the anterolateral surface of the femur and secured with four $0.9 \mathrm{~mm}$-diameter threaded Kirschner wires drilled through the plate and both cortices of the femur. Two 26-gauge stainless steel cerclage wires were tightened around the plate and bone for additional stability. With a small, oscillating saw blade (Stryker, Kalamazoo, MI), a 6-mm, critical-sized, mid-diaphyseal defect was generated. The volume of the defect was approximately 75 $\mathrm{mL}$. An implant was placed into the defect, and then the overlying muscle, fascia, and skin were closed with 4-0 Vicryl absorbable suture (Ethicon, Somerville, NJ). Animals were sacrificed at 2 and 8 weeks after surgery.

\section{D Microcomputer Tomography Evaluation}

After sacrifice, rat femurs were scanned by high-resolution three-dimensional (3D) microcomputer tomography (microCT) (SkyScan 1172F; Bruker microCT N.V., Kontich, Belgium) at an image resolution of $27.4 \mu \mathrm{m}(55 \mathrm{kV}$ and $181 \mu \AA ̊$ radiation source, using a 0.5 -mm aluminum filter) and analyzed using DataViewer, Recon, CTAn, and CTVol software version 1.15.7.0+ provided by the manufacturer (Bruker microCT N.V.). All quantitative and structural morphometric data use nomenclature described by the Nomenclature Committee of the American Society for Bone and Mineral Research. ${ }^{38}$ The global thresholding principle was applied for a threshold of 100 to all samples to isolate mineralized bone for bone volume and tissue volume measurements and calculations. Two-dimensional (2D) X-ray images were obtained by the creation of an axial cut through the center of the defect area. A volume of interest of 500 slices (approximately $10 \mathrm{~mm}$ ) centered on the middle of the defect was selected for sagittal sections and 3D reconstruction. Sagittal sectional images were generated through the mediolateral center of the femur. A volume of interest of 50 slices (approximately $1 \mathrm{~mm}$ ) centered on the middle of the defect was reconstructed for axial sectional images. Bone volume and tissue volume measurements were calculated from analyses performed for a volume of 300 slices (approximately $6 \mathrm{~mm}$ ).

Table 1 Experimental Groups for FSD Surgeries

\begin{tabular}{|c|c|c|c|c|}
\hline \multirow[b]{2}{*}{ Experimental group, concentration } & \multirow{2}{*}{$\begin{array}{l}\text { Number of } \\
\text { animals }\end{array}$} & \multirow{2}{*}{$\begin{array}{l}\text { Scaffold } \\
\text { volume, } \mu \mathrm{L}\end{array}$} & \multicolumn{2}{|c|}{ Total dose, $\mu \mathrm{g}$} \\
\hline & & & NELL-1 & BMP-2 \\
\hline \multicolumn{5}{|l|}{8 weeks } \\
\hline $300 \mu \mathrm{g} / \mathrm{mL}$ BMP2 & 3 & 75 & 0 & 22.5 \\
\hline $600 \mu \mathrm{g} / \mathrm{mL}$ BMP2 & 3 & 75 & 0 & 45 \\
\hline $600 \mu \mathrm{g} / \mathrm{mL}$ NELL-1 $+300 \mu \mathrm{g} / \mathrm{mL}$ BMP2 & 3 & 75 & 45 & 22.5 \\
\hline PBS only (control) & 3 & 75 & 0 & 0 \\
\hline $600 \mu \mathrm{g} / \mathrm{mL}$ BMP2 & 3 & 75 & 0 & 45 \\
\hline $600 \mu \mathrm{g} / \mathrm{mL} \mathrm{NELL-1}$ & 3 & 75 & 45 & 0 \\
\hline $600 \mu \mathrm{g} / \mathrm{mL}$ NELL-1 $+600 \mu \mathrm{g} / \mathrm{mL}$ BMP2 & 3 & 75 & 45 & 45 \\
\hline
\end{tabular}

BMP2, bone morphogenetic protein 2; FSD, femoral segmental defects; NELL-1, NEL-like molecule-1; PBS, phosphate-buffered saline. 


\section{Biochemical Analysis}

Finite element (biomechanical) analysis was performed using microCT images converted to DICOM files using SkyScan DICOM converter software (DicomCT application, SkyScan $1172 \mathrm{~F}$ ) according to our prior methods. ${ }^{39}$ Tetrahedral 3D mesh models were generated using a random volume of interest within the defect site (size, $0.5 \mathrm{~mm}^{3}$ ) using ScanIP software version 7 (Simpleware Ltd., Exeter, UK). Finite element analyses were performed using the ABAQUS software version 6.12 (Dassault Systèmes, Forest Hill, MD) with boundary conditions set as encastre, constrained in all directions. Next, we applied a uniform compressive pressure of $0.5 \mathrm{MPa}$ on the superior surface of the volume of interest. The von Mises stress in the samples was recorded.

\section{Histological, Immunohistochemical, and Histomorphometric Analysis}

Hematoxylin and eosin (H\&E), Masson's trichrome, and immunohistochemical staining were performed as previously described. ${ }^{26}$ Briefly, tissues were embedded in paraffin, sectioned into 5- $\mu \mathrm{m}$ slices, and deparaffinized and rehydrated before antibody addition. All primary antibodies were used at a dilution of 1:100. Appropriate secondary antibodies (Dako North America, Inc, Carpinteria, CA) were used at a dilution of 1:200. Photomicrographs were acquired using Olympus BX51 $(\times 40, \times 200$, and $\times 400$ magnification lens, UPLanFL; Olympus, Center Valley, PA) and SZX12 microscopes $(\times 10$ magnification lens, DF PLAPO $1.2 \times$ pf; Olympus) and a MicroFire digital microscope camera with ImageFrame software version 2.1 (Optronics, Goleta, CA). Staining intensity was quantified using ImagePro Plus (Media Cybernetics, Rockville, MD). Results are reported as the intensity measurements from eight random fields at $\times 200$ magnification.

Oil red $\mathrm{O}$ staining was performed on $10-\mu \mathrm{m}$ frozen sections using a $0.3 \%$ oil red $\mathrm{O}$ solution in $60 \%$ isopropyl alcohol $/ 40 \% \mathrm{ddH}_{2} \mathrm{O}$ for 15 minutes. Slides were counterstained with hematoxylin for 15 seconds to visualize nuclei. The intensity of oil red $\mathrm{O}-$ positive staining was quantified using ImagePro Plus in eight separate random fields at $\times 200$ magnification.

Histomorphometric analyses were performed on H\&Estained sections. Only regions within the defect region containing newly formed trabecular bone were analyzed. The histomorphometric parameters of bone area, tissue area, trabecular number, trabecular perimeter, trabecular width, and trabecular spacing were measured at $\times 100$ magnification and analyzed using Photoshop CS5 (Adobe Systems, San Jose, CA) as previously described. ${ }^{40}$ Five sections per specimen were analyzed. All histomorphometric measurements in each specimen were assessed blindly (X.Z., J.S., and K.S.L.), and all nomenclature, symbols, and units are used per established American Society for Bone and Mineral Research conventions. ${ }^{41}$

\section{Cell Culture}

The M2-10B4 cell line, a clone derived from bone marrow stromal cells (BMSCs) from a $(\mathrm{C} 57 \mathrm{BL} / 6 \mathrm{~J} \times \mathrm{C} 3 \mathrm{H} / \mathrm{HeJ}) \mathrm{F} 1$ mouse, ${ }^{42}$ was purchased from ATCC (Manassas, VA). Cells were maintained in growth medium [RPMI 1640 (Invitrogen, Carlsbad, CA) supplemented with $10 \%$ heat-inactivated fetal bovine serum, $1 \mathrm{mmol} / \mathrm{L}$ sodium pyruvate, and $100 \mathrm{U} / \mathrm{mL}$ penicillin/streptomycin]. Osteogenic differentiation medium consisted of RPMI 1640, 10\% FBS, $50 \mu \mathrm{g} / \mathrm{mL}$ ascorbic acid, and $3 \mathrm{mmol} / \mathrm{L} \beta$-glycerophosphate. Growth medium only was used for adipogenic differentiation studies as previously reported. $^{43}$

Primary human BMSCs were purchased from PromoCell (Heidelberg, Germany). Cells were cultured using Mesenchymal Stem Cell Growth Medium (C-28010; PromoCell). In vitro osteogenesis and adipogenesis were induced by mesenchymal stem cell osteogenic differentiation medium (Mesenchymal Stem Cell Growth Medium plus $50 \mu \mathrm{g} / \mathrm{mL}$ ascorbic acid and $3 \mathrm{mmol} / \mathrm{L} \quad \beta$-glycerophosphate) ${ }^{44}$ and Mesenchymal Stem Cell Adipogenic Differentiation Medium (C-28011; PromoCell).

For osteogenic or adipogenic differentiation, M2-10B4 cells or human BMSCs were seeded at $1 \times 10^{5}$ cells per well or $8 \times 10^{4}$ cells per well, respectively, in 24 -well plates for 24 hours, and then cultured with differentiation medium with NELL-1 and/or BMP2.

\section{RNA Extraction, Real-Time PCR, and Immunoblot Analysis}

Total RNA extraction and real-time PCR were performed as previously described. ${ }^{45}$ SYBR green real-time PCR primer sequences for mouse M2-10B4 cells are given in Table 2. For human BMSCs, TaqMan primer-probe sets HS99999905_m1 (glyceraldehyde-3-phosphate dehydrogenase), Hs01115513m1 (PPAR $\gamma$ ), Hs02915002-s1 (C/EBP $\alpha)$, Hs00609452-g1 [osteocalcin (OCN)], and Hs00959010-m1 [osteopontin (OPN)] were used (Applied Biosystems, Carlsbad, CA). All fold-change values from three independent experiments are reported.

Nuclear and cytoplasmic proteins were isolated using an NE-PER Nuclear and Cytoplasmic Extraction Kit (Thermo Scientific, Rockford, IL). Western blot analysis was performed as previously described ${ }^{26}$ using antibodies against $\operatorname{PPAR} \gamma, \mathrm{C} / \mathrm{EBP} \alpha$, and $\beta$-catenin at a dilution of $1: 1000$.

\section{In Vitro Staining and Alkaline Phosphatase Activity Assay}

For oil red $\mathrm{O}$ staining of cultured cells, monolayers were rinsed with PBS, fixed with $10 \%$ formalin for 1 hour at room temperature, and stained with $3 \%$ oil red $\mathrm{O}$ solution (see Histological, Immunohistochemical, and Histomorphometric Analysis) for 10 minutes. Adipocytes were quantified through counting of oil red $\mathrm{O}$-positive cells in four wells per experimental condition. Results are reported from 16 random fields at $\times 200$ magnification. Alizarin red staining and alkaline 
Table 2 Mouse Primer Sequences for Real-Time PCR

\begin{tabular}{|c|c|c|}
\hline Gene & Forward primer & Reverse primer \\
\hline Gapdh & 5'-TGCACCACCAACTGCTTAGC-3' & 5'-CCACCACCCTGTTGCTGTAG-3' \\
\hline Pparg & $5^{\prime}$-GGAAAGACAACGGACAAATCA- $3^{\prime}$ & 5'-TACGGATCGAAACTGGCAA- $3^{\prime}$ \\
\hline Alp & 5'-TGCCACTGTGAGAAGACCTG-3' & 5'-TGCACAGGAAGTGAGTCTGG-3' \\
\hline Runx2 & $5^{\prime}-\mathrm{CCGCACGACAACCGCACCAT-3^{ \prime }}$ & 5'-CGCTCCGGCCCACAAATCTC-3' \\
\hline Ocn & 5'-GCAATAAGGTAGTGAACAGACTCC-3' & 5'-AGCAGGGTTAAGCTCACACTG-3' \\
\hline
\end{tabular}

phosphatase activity assays were performed as previously described. $^{26}$

\section{Immunocytochemistry}

M2-10B4 cells were seeded on Millicell EX Slides (PEZGS0816, Millipore) at $5 \times 10^{4}$ cells per well in RPMI $1640+10 \%$ FBS for 24 hours and serum starved in RPMI $1640+1 \%$ FBS overnight. After 2 hours of treatment, cells were fixed using ice-cold acetone for 10 minutes. Anti-active $\beta$-catenin antibody (Millipore) was applied at a dilution of 1:200. ABC complex (Vector Laboratories, Burlingame, CA) was applied to the sections after incubation with biotinylated secondary antibody (Dako). AEC Substrate (Dako) was used as a chromogen, and the sections were lightly counterstained with hematoxylin. Photomicrographs were acquired using an Olympus BX51 device (×200 UPLanFL magnification lens).

\section{Luciferase Reporter Assay}

M2-10B4 cells were transfected with $20 \mu \mathrm{g}$ of Super(16×) TOPFLASH (TCF/LEF reporter plasmid) and $1 \mu \mathrm{g}$ of Renilla luciferase plasmids for 24 hours and then seeded at $4.0 \times 10^{3}$ cells per well in 96-well plates. Cells were starved in RPMI $1640+1 \%$ FBS overnight and then treated with BMP2 and/ or NELL-1. Luciferase activity was measured 48 hours after treatment using Dual Luciferase Reporter Assay System (Promega, Madison, WI) per the manufacturer's instructions.

\section{Preparation of Lentiviral Vectors for Runx2 Reporter Assays}

The transduction plasmid for preparing lentiviral vector carrying the Runx2 P1-enhanced green fluorescent protein (EGFP) expression cassette (Runx2-EGFP reporter) was prepared by substituting the cytomegalovirus promoter in the pRRL-cPPT-CMV-X-PRE-SIN plasmid $^{46}$ with the mouse Runx2 P1 promoter. The mouse Runx2 P1 promoter was obtained by PCR of mouse genomic DNA (forward primer, 5'-GCGAATTACTCGAGAGCAGCACTGTTGCTCAGAA-3'; reverse primer, 5'-GCGAATGCCCGGGTCACACAATCCAAAAAAGC-3' ${ }^{\prime}$ ). 293T cells were cotransfected with the transduction plasmids, the package plasmid pCMV-dR8.2-vprX, and the envelope plasmid
pCMV-VSVG. ${ }^{47}$ The viral vectors were collected at 2 to 4 days after transfection and were filtered, and concentrated. The concentrations of viral vector were quantified by a count of the core protein p24 by enzyme-linked immunosorbent assay as previously described. ${ }^{47}$

\section{Cell Infection}

M2-10B4 cells were seeded in 24-well cell culture plates at $2 \times 10^{4}$ cells per well 16 hours before infection. Viral vectors with p24 counts of $0.4 \mu \mathrm{g}$ were added to each well in 24-well plates. Three hours after infection, the viral vectors were washed away, and fresh medium was added to the cultures. At 24 hours after infection, BMP2 and/or NELL-1 were added into the culture media.

\section{Flow Cytometric Assay of GFP-Positive Cells}

Cells were trypsinized and collected 3 days after infection. Flow cytometry was performed to quantify GFP expression in the collected cells using a Cytomics FC500 cell sorter (Beckman Coulter, Brea, CA). Cells infected with mock vector were used as the negative control to establish gates. The percentages of GFP-positive cells were counted to quantify the expression of GFP in the infected cultures.

\section{Statistical Analysis}

Means \pm SDs were calculated from numerical data. To allow for multiple comparisons between groups, statistical analyses were performed using one-way analysis of variance for singlevariable comparisons and two-way analysis of variance for dual-variable comparisons (ie, experiments involving both Dkk or XAV939 and BMP2 and/or NELL-1). This procedure was followed by a post hoc Tukey range test to directly compare the data between the two groups. $P<0.05$ was considered to be significant for all statistical tests used.

\section{Results}

\section{NELL-1 Inhibits BMP2-Induced Cystlike Bone Formation in Vivo}

Although the 300 and $600 \mu \mathrm{g} / \mathrm{mL}$ BMP2 concentrations used here are less than the $1.5 \mathrm{mg} / \mathrm{mL}$ concentration used 
clinically, these concentrations are sufficient for reproducible induction of abnormal bone formation in a rat FSD model, as we have previously described. ${ }^{12}$ In addition, we used NELL-1 at $600 \mu \mathrm{g} / \mathrm{mL}$ because we previously showed that this NELL-1 concentration in a demineralized bone matrix carrier was able to induce fusion in an FSD model. $^{37}$ PLGA scaffolds containing PBS, BMP2, or NELL-1+BMP2 combined, were implanted into rat FSDs (Figure 1A).

We performed high-resolution $2 \mathrm{D}$ radiography and 3D microCT reconstructions of the defect sites 8 weeks after surgery. Control defects treated with PBS exhibited definitive non-union. In contrast, BMP2 treatment alone resulted in bone fusion, but the newly formed bone was characterized peripherally by a thin, continuous cortical shell that extended well beyond the original bony defect margins and internally by sparse and thin trabeculae formation. Strikingly, NELL$1+\mathrm{BMP} 2$ cotreatment produced bone fusion, with newly formed bone confined mostly to the defect sites with considerably thicker cortical architecture and a much denser, native bonelike, trabecular structure compared with the BMP2-only group (Figure 1B). Notably, NELL-1 on PLGA scaffolds increased bone regeneration compared with that in controls, but did not induce bony fusion at up to 12 weeks after surgery (Supplemental Figure S1), unlike NELL-1 on demineralized bone matrix scaffolds. ${ }^{37}$

On quantitative microCT analysis of bone volume and tissue volume (Figure 1, C and D, respectively), all
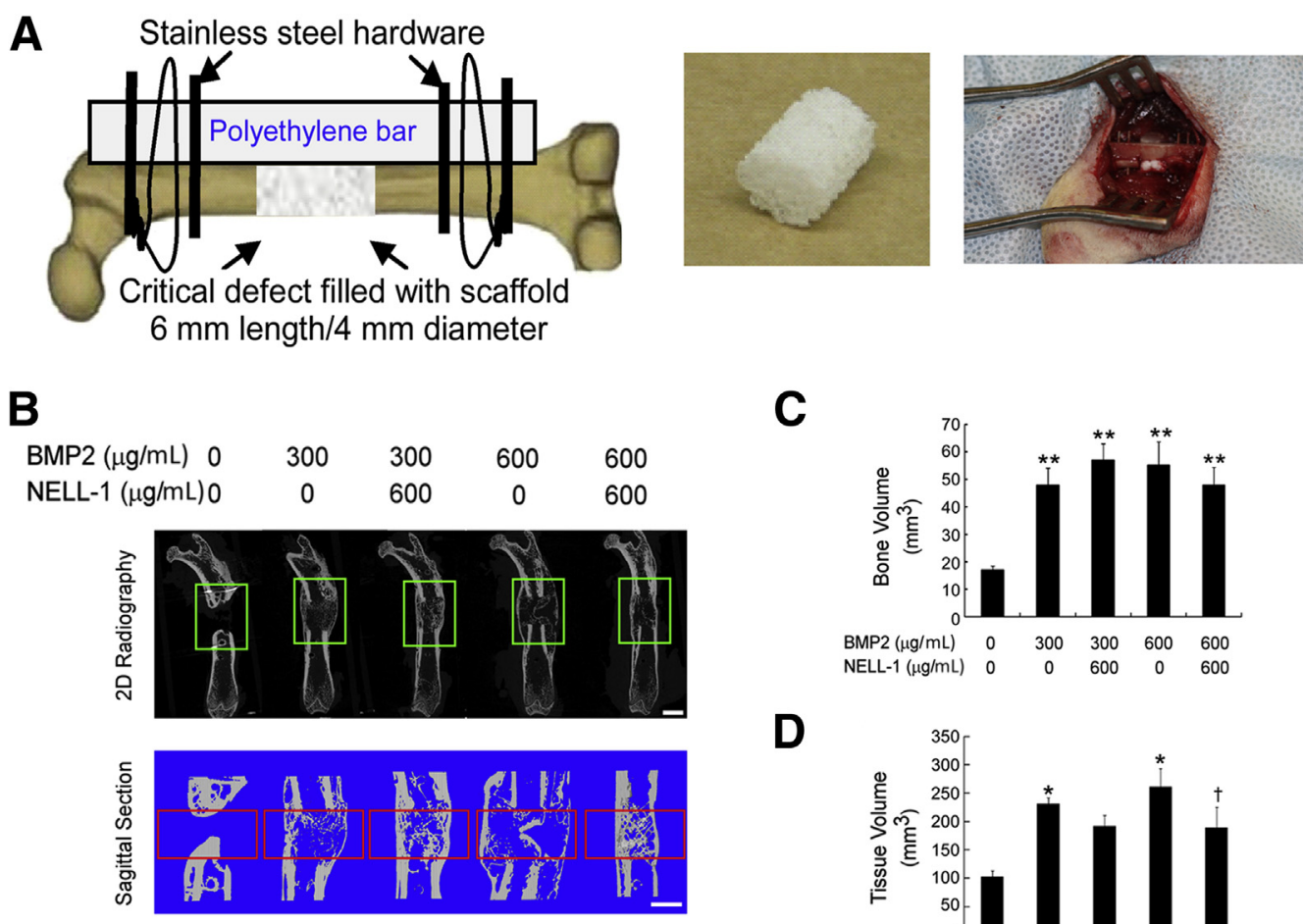

D
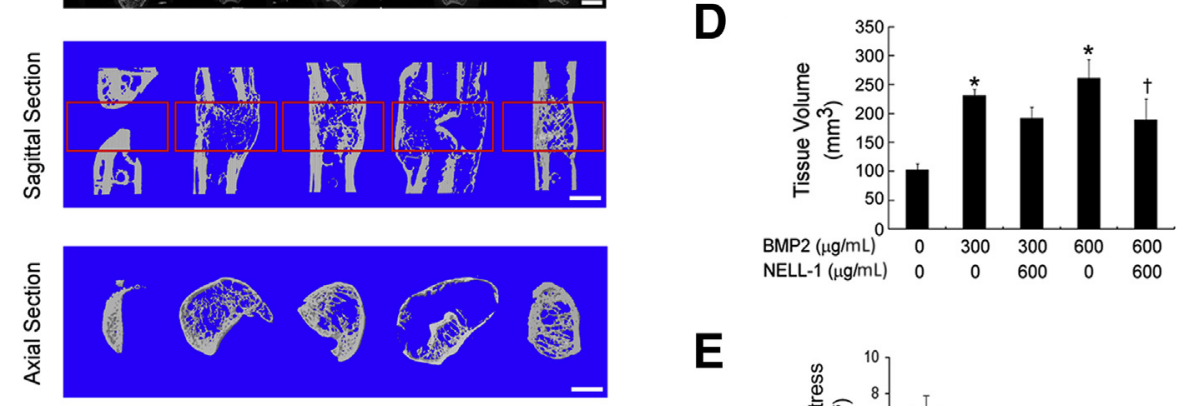

E

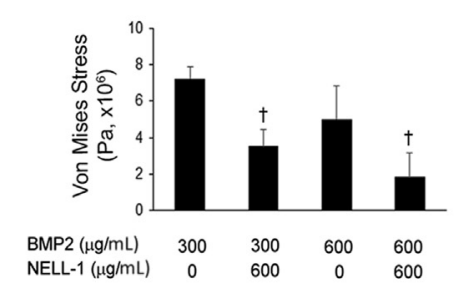

Figure 1 Microcomputer tomography (microCT) and biomechanical evaluation of femoral segmental defects (FSDs) at 8 weeks after surgery reveals induction of cystlike bone formation with bone morphogenetic protein 2 (BMP2) alone and suppression of this effect by addition of NEL-like molecule-1 (NELL-1). BMP2 dose: 300 or $600 \mu \mathrm{g} / \mathrm{mL}$. NELL-1 dose: $600 \mu \mathrm{g} / \mathrm{mL}$. A: Left panel, schematic of FSD surgical procedure; middle panel, hydroxyapatite-coated PLGA scaffold implanted into defect; right panel, intraoperative photograph after scaffold implantation. B-D: From top to bottom, two-dimensional (2D) radiography, sagittal section, axial section, and three-dimensional (3D)-reconstructed microcT images (B). Green boxes indicate the region of interest selected for microCT reconstruction below. BMP2 treatment results in formation of abnormal bone extending beyond the cortical margins, which is not observed with NELL-1+BMP2 co-treatment. Red boxes indicate the region of interest selected for quantification of bone volume (C) and tissue volume (D). E: Finite element analysis and quantification of von Mises stress. Data are expressed as means \pm SD. ${ }^{*} P<0.05,{ }^{*} P<<0.01$ versus control group; ${ }^{\dagger} P<0.05$ versus same dose of BMP2. $n=3$ (C and D). Scale bar $=5 \mathrm{~mm}(\mathbf{B})$. 
treatments significantly increased bone volume compared with no treatment; however, no statistically significant difference in bone volume between the BMP2-only and NELL$1+\mathrm{BMP} 2$ cotreatment groups was observed. On the other hand, NELL-1+BMP2 cotreatment significantly reduced tissue volume compared with BMP2 treatment alone. Moreover, computer-simulated biomechanical (finite element analysis) testing demonstrated increased bone strength with BMP2+NELL-1 cotreatment compared with BMP2 only (Figure 1E). Taken together, these measurements indicate that similar amounts of bone were induced by either BMP2 treatment alone or NELL-1+BMP2 cotreatment, but the bone was distributed throughout a larger volume of tissue with BMP2-only treatment compared with NELL$1+\mathrm{BMP} 2$ cotreatment.

We next analyzed the bone quality of FSDs treated with PBS only (control), BMP2 alone, or NELL-1+BMP2 by histological examination of specimens collected at 8 weeks
A

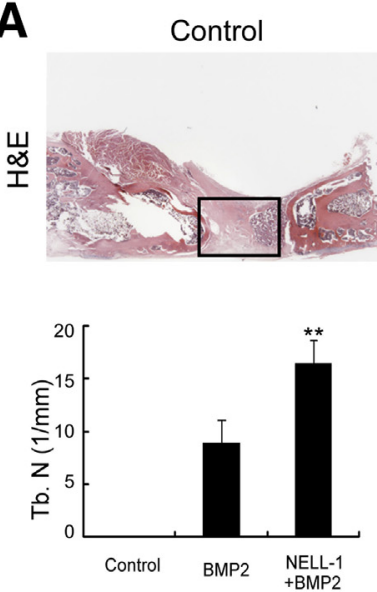

B

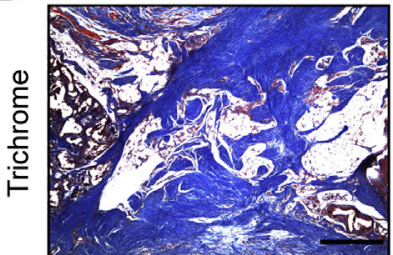

C

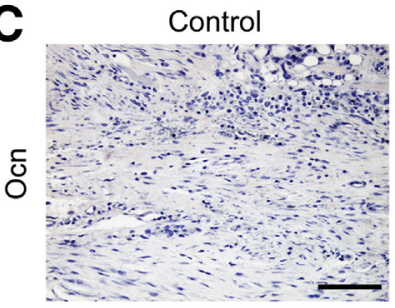

D

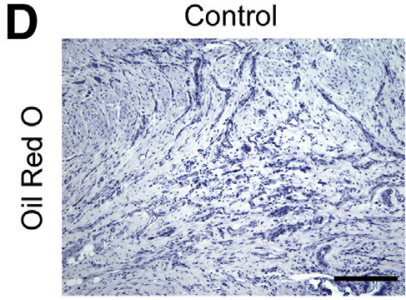

BMP2
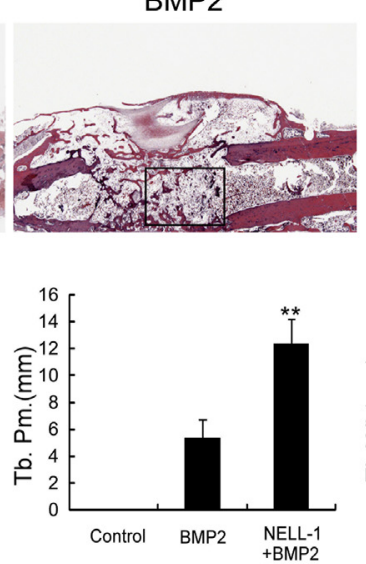

BMP2

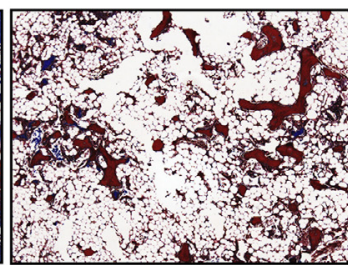

BMP2

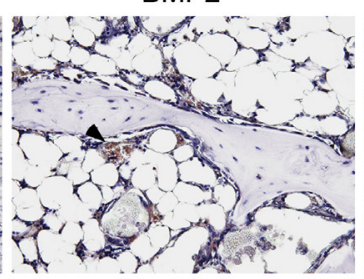

BMP2

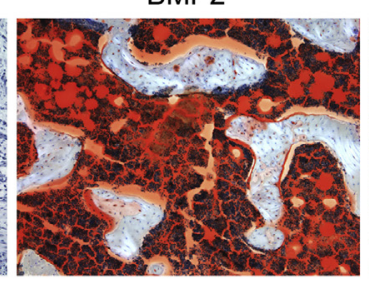

NELL-1+BMP2
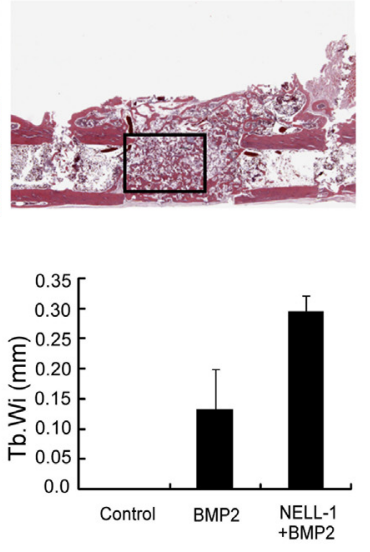

NELL-1+BMP2

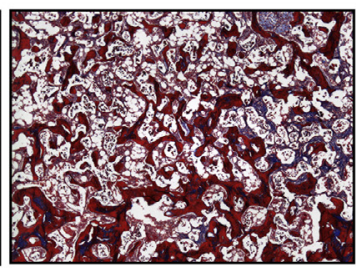

NELL-1+BMP2

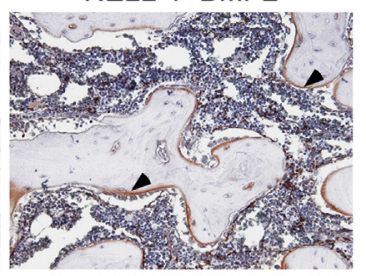

NELL-1+BMP2

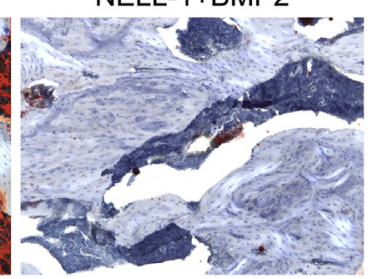

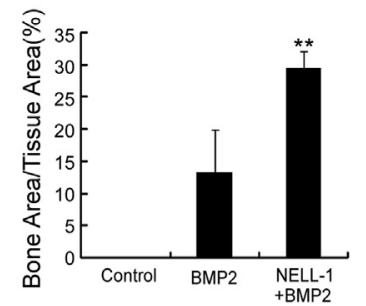

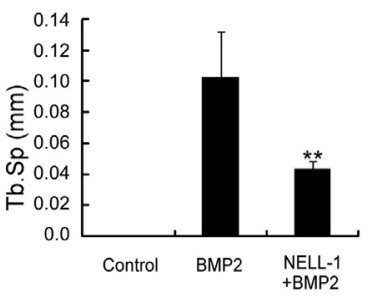

+BMP2
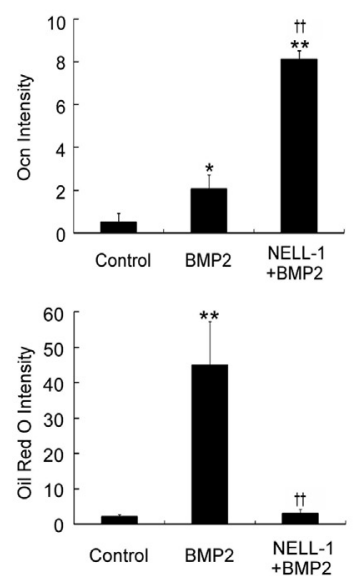

Figure 2 Histological evaluation at 8 weeks after surgery reveals increased osteogenesis with NEL-like molecule-1 (NELL-1) + bone morphogenetic protein 2 (BMP2) cotreatment and reduction of adipogenesis induced by BMP2. BMP2 dose, $600 \mu \mathrm{g} / \mathrm{mL}$; NELL-1 dose, $600 \mu \mathrm{g} / \mathrm{mL}$. A: Hematoxylin and eosin (H\&E) staining reveals a large extension of bone surrounded by thin cortical bone in BMP2-only samples, which is not observed in phosphate-buffered saline control or NELL1+BMP2 co-treated samples. The boxed areas indicate the regions magnified in B. Boundaries of defect are as indicated. Histomorphometric analyses are based on H\&E staining. B: Masson's trichrome staining reveals fibrous tissue (light blue) in control samples, abundant adipocytes (large white droplets) in BMP2-only samples, and osteoid matrix (dark blue) ossifying into mature trabecular bone (red) in NELL-1+BMP2 co-treated samples. C: 0steocalcin (0cn) immunohistochemical analysis. Arrowheads indicate positive $0 \mathrm{cn}$ staining and its quantification. D: 0il red 0 staining and its quantification. Data are expressed as means \pm SD. ${ }^{*} P<0.05,{ }^{*} P<0.01$ versus control group; ${ }^{\dagger \dagger} P<0.01$ versus same dose of BMP2. $n=3$ (B and D). Scale bars: $4 \mathrm{~mm}(\mathbf{A}), 1 \mathrm{~mm}(\mathbf{B}), 0.2 \mathrm{~mm}(\mathbf{C}), 0.4 \mathrm{~mm}$ (D). Def, extent of defect area; Tb. N, trabecular number; Tb. Pm., trabecular perimeter; Tb.Sp, trabecular spacing; Tb.Wi, trabecular width. 
after surgery (Figure 2). The control defects exhibited definitive fibrous non-union of the femoral cortices, with no trabecular bone formation at the defect centers. BMP2 treatment alone induced fracture union, but the newly formed bone contained exuberant adipose tissue interspersed with sparse trabecular bone that was surrounded by a thin cortical bone shell extending up to approximately 4 $\mathrm{mm}$ beyond the original bone defect margins. In contrast, NELL-1+BMP2 cotreatment generated tightly woven, trabecular bone largely confined to the defect sites. Histomorphometric analyses on serial H\&E-stained sections showed increased bone area/tissue area ratio, trabecular number, perimeter, and width, and reduced trabecular spacing in NELL-1+BMP2 treated samples. Masson's trichrome staining and immunostaining for osteocalcin (Ocn), a marker of bone matrix and osteoblastic differentiation, confirmed that NELL-1+BMP2 cotreated defects exhibited increased bone formation with denser trabeculations than with BMP2 treatment alone. To specifically assess and quantify adipogenic differentiation observed by $H \& E$ and Masson's trichrome histological examination, we performed oil red $\mathrm{O}$ staining on cryosectioned specimens. Consistent with our previous histological findings, ${ }^{12}$ BMP2 treatment alone significantly increased the intensity of oil red $\mathrm{O}$ staining, an effect notably absent with NELL-1+BMP2 cotreatment.

To gain better insight on the early cellular effects of NELL-1 and BMP2 on defect healing, we evaluated NELL-1, BMP2, or NELL-1+BMP2 treated FSDs at 2 weeks after surgery (Figure 3). Our published findings show that Nell-1 does not form ectopic bone, ${ }^{26}$ but that Nell-1 does form robust bone growth when in the presence of an osteogenic cell source such as BMSCs. ${ }^{11}$ In agreement with our previous studies, NELL-1 treatment alone did not result in inappropriate expansion of bone tissue into the muscle compartment. ${ }^{11}$ Instead, new bony trabeculations arising from the cut femoral bone ends were observed growing into the defect. In contrast, BMP2-only samples exhibited a massive reactive tissue zone characterized by increased cellularity in the muscle and bone defect compartments that extended well beyond the original margins of the bone defect site. Meanwhile, NELL-1+BMP2 cotreatment induced a much smaller reactive tissue zone, with increased trabecular bone largely confined to the original bone defect area, and with minimal tissue reactivity in the muscle compartment. Together, our microCT and histological data indicate that NELL-1 reduces BMP2-induced exuberant bone formation and adipogenesis to improve BMP2-mediated osteogenesis.

\section{NELL-1 Reduces BMP2-Induced Adipogenesis}

We previously observed that goat BMSCs transduced with adenoviral $B M P 2$ and injected into nude mouse muscle pouch models form large bone voids filled with fatty tissue. ${ }^{11}$ This phenomenon was also observed with BMP2 use in dog models and in humans. ${ }^{27,28}$ Furthermore, forced Nell1 and Bmp2 overexpression by adenoviral treatment produces more bone than either adenoviral Nell1 or Bmp2 alone in a nude mouse muscle pouch model. ${ }^{26}$

To further analyze the effects of NELL-1 on BMP2induced adipogenesis, we focused on the expression of Ppar $\gamma$ and $\mathrm{C} / \mathrm{Ebp} \alpha$, two important transcriptional regulators
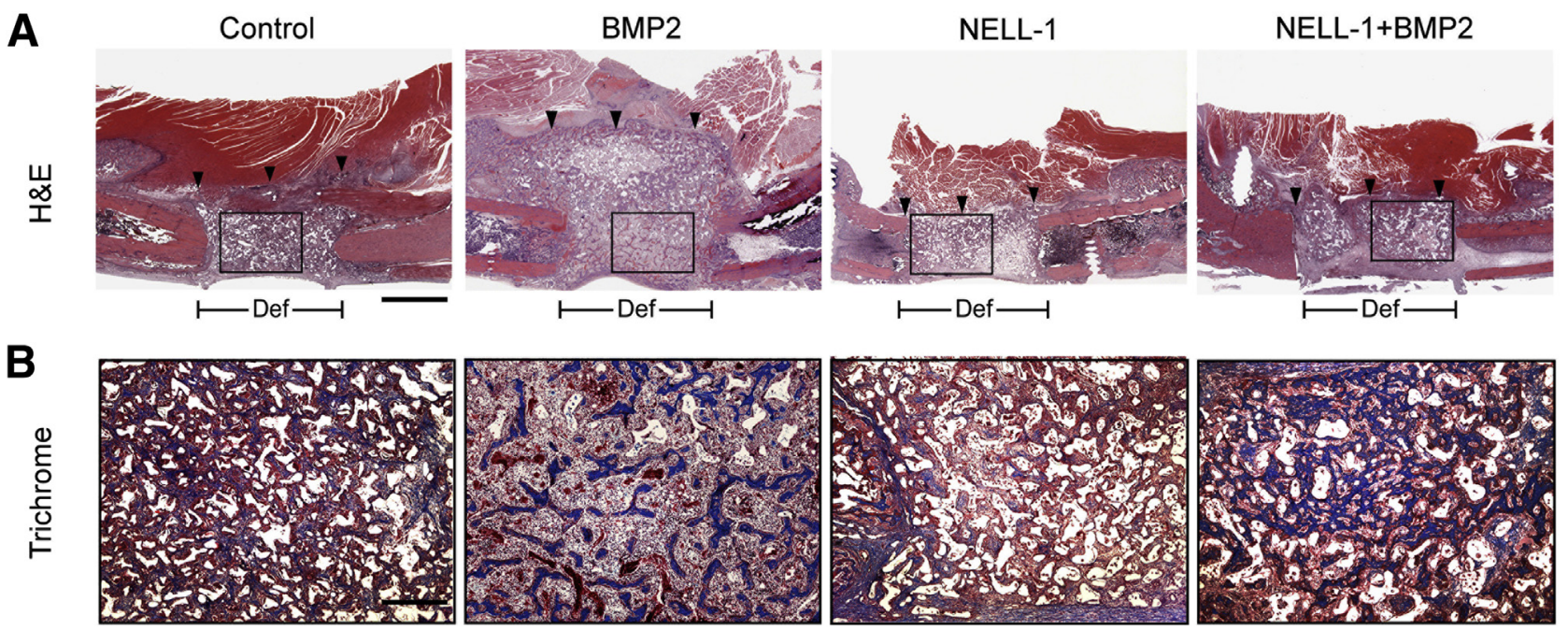

Figure 3 Histological evaluation at 2 weeks after surgery. A: Hematoxylin and eosin (H\&E) staining demonstrates increased cellularity and aberrant expansion of bone tissue into the muscle compartment with bone morphogenetic protein 2 (BMP2) treatment alone as early as 2 weeks, but not with NEL-like molecule-1 (NELL-1) treatment alone or NELL-1+BMP2 cotreatment. The boxed areas indicate the regions magnified in B. Arrowheads indicate the lateral limit of new tissue formation. BMP2 dose: $600 \mu \mathrm{g} / \mathrm{mL}$; NELL-1 dose, $600 \mu \mathrm{g} / \mathrm{mL}$. B: Trichrome staining for mature mineralized bone (red) and osteoid matrix (blue). Please note that the implanted scaffold also appears red. In the defect site, NELL-1+BMP2 cotreatment induces more trabecular bone than does BMP2 treatment alone, but BMP2 alone also increases cellularity and induces a tissue reaction containing poorly trabeculated bone and fibrous tissue outside of the cortical margin of the defect. The same location in the other groups contains primarily muscle tissue only. $n=3$ (B). Scale bars: $4 \mathrm{~mm}$ (A), $1 \mathrm{~mm}$ (B). Def, extent of defect area. 
of adipogenesis ${ }^{48,49}$ (Figure 4). PPAR $\gamma$ immunohistochemistry of the increased adipogenesis observed by histological examination was used for analyzing FSD specimens collected 2 weeks after surgery. Samples treated with BMP2 alone exhibited strong Ppary staining in the cells surrounding and between the trabeculae at the defect center, consistent with increased adipogenesis. Importantly, NELL-1 significantly repressed BMP2-induced Ppar $\gamma$ expression in NELL-1+BMP2 cotreated animals. We next sought to replicate these findings in vitro using the mouse BMSC line M2-10B4 under adipogenic conditions, as previously described. ${ }^{43}$ At 9 days, BMP2-induced lipid accumulation was increased more than fivefold, as assessed by oil red $\mathrm{O}$ staining. However, the addition of NELL-1 antagonized the proadipogenic effects of BMP2 and significantly reduced both Ppar $\gamma$ and C/Ebp $\alpha$ expression. Because the effects of BMP2 on BMSCs may be species dependent, ${ }^{50}$ and because cell lines may respond differently from primary cells, we also confirmed the inhibitory effects of NELL-1 on BMP2-induced adipogenesis using primary rat BMSCs (Supplemental Figure S2A) and primary human BMSCs.
These data confirm that NELL-1 inhibits BMP2-stimulated adipogenesis in vitro in BMSCs from multiple species.

\section{NELL-1 Enhances BMP2-Induced Osteogenesis}

To determine whether the suppression of adipogenesis corresponded with an increase in osteogenesis, we analyzed Runx2 expression in the centers of FSDs collected 2 weeks after surgery (Figure 5A). Runx2 expression was significantly increased with NELL-1+BMP2 cotreatment compared with BMP2 treatment alone. To model this effect in vitro, M2-10B4 cells were cultured under osteogenic conditions (Figure 5, B and C). As expected, NELL-1 and BMP2 alone increased the expression of markers of early (Runx2 expression), intermediate (alkaline phosphatase and osteopontin), and terminal osteogenic differentiation (osteocalcin expression and alizarin red-positive bone nodules) over those in controls. However, when added together, NELL-1+BMP2 significantly increased all osteogenic markers relative to NELL-1 or BMP2 alone, consistent with our 8-week imaging and histological findings of
A
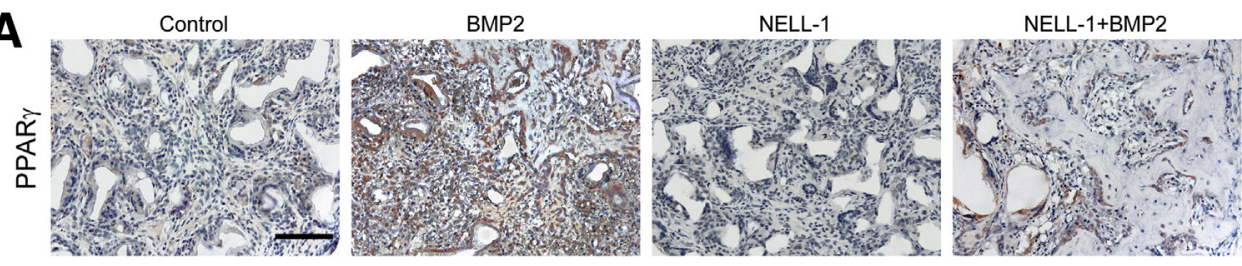

B
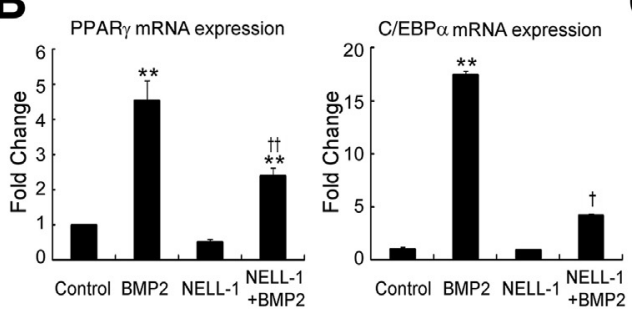

C
D

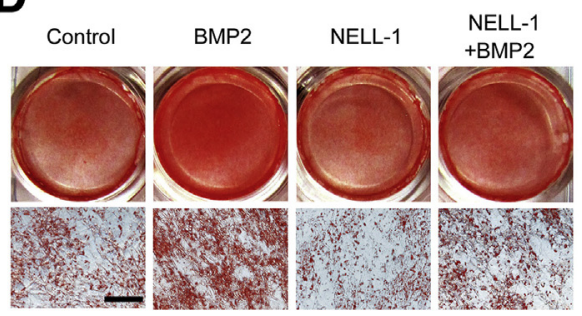

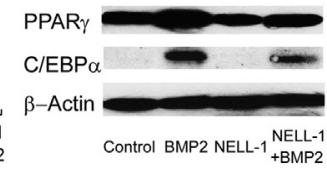

$\mathbf{E}$

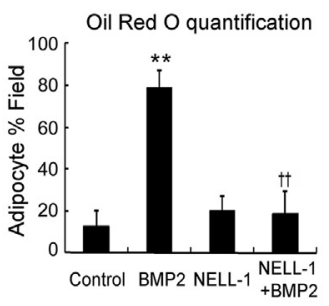

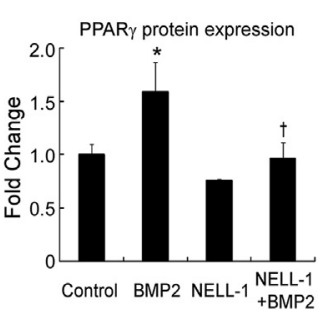

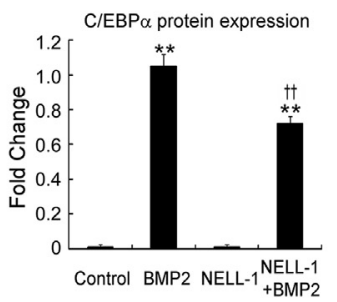

Figure 4 Addition of NEL-like molecule-1 (NELL-1) reduces bone morphogenetic protein 2 (BMP2)-induced adipogenesis. A: Peroxisome proliferatoractivated receptor $\gamma$ (PPAR $\gamma$ ) immunohistochemical analysis of femoral segmental defects (FSDs; within the scaffold implant) at 2 weeks after surgery reveals increased expression induced by BMP2 treatment alone but not NELL-1+BMP2 cotreatment. BMP2 dose, $600 \mu \mathrm{g} / \mathrm{mL} ; \mathrm{NELL}-1 \mathrm{dose}, 600 \mu \mathrm{g} / \mathrm{mL}$. Quantitation of PPAR $\gamma$ staining is show in graph to the right. B-D: M2-10B4 cells were treated with phosphate-buffered saline (PBS) only (control), $800 \mathrm{ng} /$ $\mathrm{mL} \mathrm{NELL-1,} \mathrm{and/or} 300 \mathrm{ng} / \mathrm{mL}$ BMP2 under adipogenic differentiation. The expression of PPAR $\gamma$ and CCAAT enhancer-binding protein $\alpha(C / E B P \alpha)$ was determined on day 3 by real-time PCR (B) and Western blot analysis with quantification of PPAR $\gamma$ and C/EBP $\alpha(C)$. D: Lipid accumulation was visualized by oil red 0 staining at 9 days and quantified by light microscopy from eight random areas. E: Real-time PCR analysis of PPARG and CEBPA expression in human primary bone marrow stromal cells (BMSCs) treated with PBS, $800 \mathrm{ng} / \mathrm{mL} \mathrm{NELL-1,} \mathrm{and/or} 300 \mathrm{ng} / \mathrm{mL}$ BMP2 for 2 days. All fold-changes are reported relative to control group. Data are expressed as means \pm SD. ${ }^{*} P<0.05,{ }^{*}{ }^{*} P<0.01$ versus control group; ${ }^{\dagger} P<0.05,{ }^{\dagger} P<0.01$ versus same dose of BMP2. $n=3$ (A, C, and $\mathbf{E}), n=4(\mathbf{D})$. Scale bars $=0.2 \mathrm{~mm}(\mathbf{A}$ and $\mathbf{D})$. 

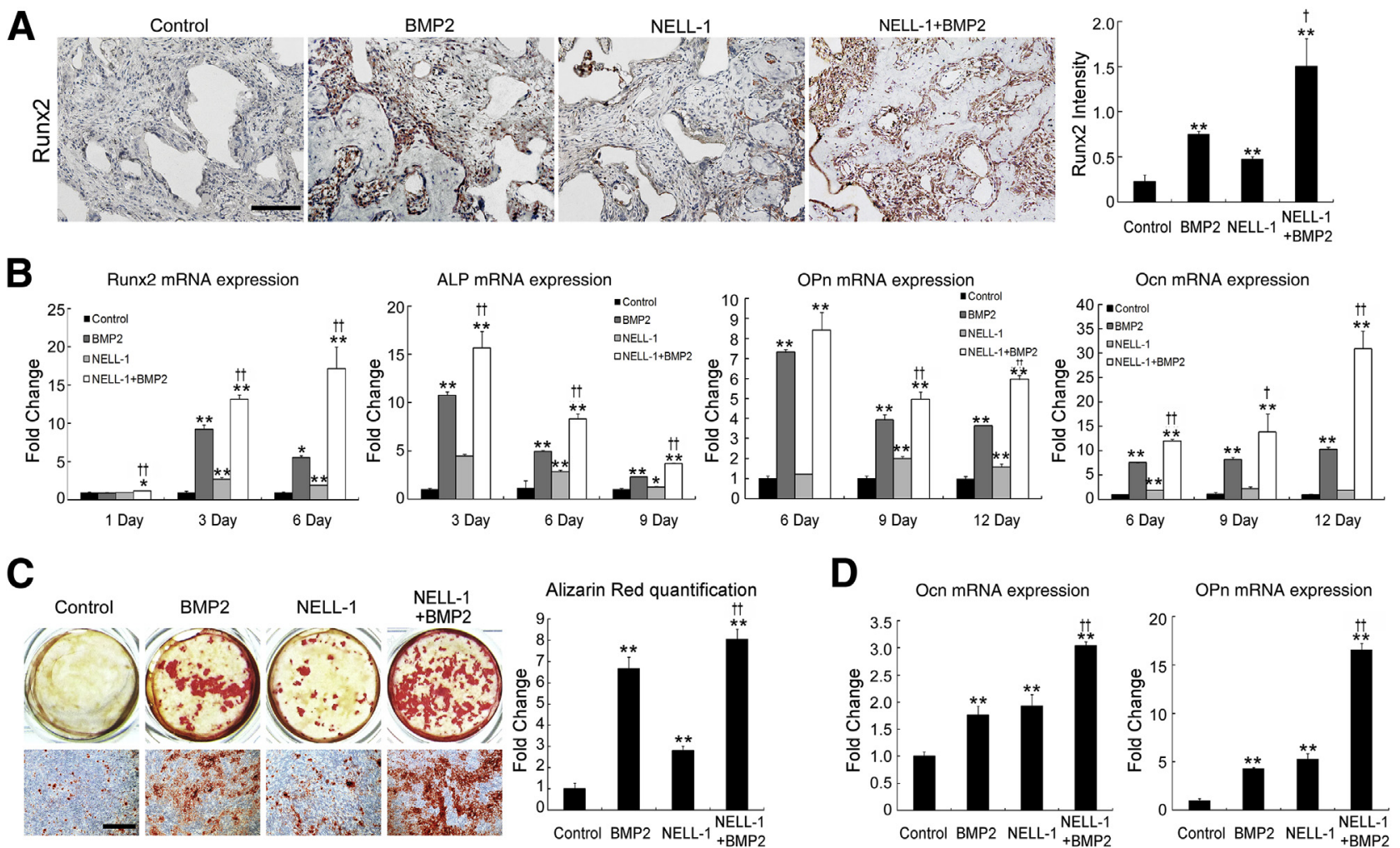

Figure 5 Addition of NEL-like molecule-1 (NELL-1) enhances bone morphogenetic protein 2 (BMP2)-induced osteogenesis. A: Expression of runt-related transcription factor 2 (Runx2) in NELL-1 and BMP2-treated samples of femoral segmental defect (FSD; within the scaffold implant) at 2 weeks after surgery. BMP2 dose, $600 \mu \mathrm{g} / \mathrm{mL}$; NELL-1 dose, $600 \mu \mathrm{g} / \mathrm{mL}$. Runx2-positive cells appear primarily adjacent to trabecular bone. Quantification of Runx2 staining is shown in graph to the right. B and C: M2-10B4 cells were treated with phosphate-buffered saline, $800 \mathrm{ng} / \mathrm{mL}$ NELL-1, and/or $100 \mathrm{ng} / \mathrm{mL}$ BMP2 under osteogenic differentiation conditions. B: Real-time PCR analysis of osteogenic differentiation marker gene. Runx2 expression was assessed at 1, 3, and 6 days; ALP expression was assessed at 3, 6, and 9 days; Ocn and Opn expressions were analyzed at 6, 9, and 12 days. C: Mineralization was visualized by Alizarin red staining at 12 days and quantified by light microscopy from eight random areas. D: Real-time PCR analysis of OCN and OPN expressions in human primary bone marrow stromal cells (BMSCS) treated with NELL-1 and/or BMP2 for 6 days. All fold-changes are reported relative to control group. Data are expressed as means \pm SD. ${ }^{\star} P<0.05$, ${ }^{*} P<0.01$ versus control group; ${ }^{\dagger} P<0.05,{ }^{\dagger} P<0.01$ versus same dose of BMP2. $n=3$ (A, B, and $\left.\mathbf{D}\right), n=4$ (C). Scale bars $=0.2 \mathrm{~mm}(\mathbf{A}$ and $\mathbf{C})$.

high-quality bone formation. Repeating these experiments in primary human BMSCs (Figure 5D) showed that NELL-1 significantly increased OCN and OPN expression in human BMSCs in combination with BMP2.

\section{NELL-1 Induces Canonical Wnt Signaling}

Because NELL-1 was previously found to activate canonical Wnt signaling in both MSC and osteoclastic cell types, ${ }^{39}$ we hypothesized that NELL-1-mediated effects may involve canonical Wnt activation. We first examined in vitro activation of canonical Wnt signaling by immunocytochemical staining of M2-10B4 cells using an antibody against active $\beta$-catenin (Figure 6A). BMP2 did not induce $\beta$-catenin nuclear accumulation at either $100 \mathrm{ng} / \mathrm{mL}$ or 300 $\mathrm{ng} / \mathrm{mL}$, whereas NELL-1+BMP2 cotreatment stimulated more $\beta$-catenin nuclear accumulation compared with BMP2 alone. Next, Western blot analysis of M2-10B4 cytoplasmic and nuclear fractions (Figure 6B) showed significantly increased nuclear $\beta$-catenin levels after treatment with NELL-1+BMP2 compared with BMP2 only. Similarly, the TOPFlash canonical Wnt reporter assay demonstrated no luciferase activity induced by BMP2, and restored luciferase activity induced by NELL-1+BMP2 (Figure 6C). Next, we examined in vivo activation of Wnt signaling by immunohistochemical staining for $\beta$-catenin (Figure 6D) in the same FSD specimens used for Ppar $\gamma$ (Figure 4A) and Runx2 (Figure 5A) staining. Increased nuclear $\beta$-catenin localization was observed only in NELL-1+BMP2 cotreatment groups. The BMP2-alone group revealed primarily cytoplasmic $\beta$-catenin staining. Taken together, these in vitro and in vivo results demonstrate a novel NELL-1 function to induce canonical Wnt activity and suggest that NELL-1 regulation of BMP2-induced osteogenesis and adipogenesis may occur through activation of canonical Wnt signaling.

\section{Canonical Wnt Signaling Is Required for NELL-1 Effects} on BMP2-Induced Lineage Differentiation

To determine whether NELL-1 repression of BMP2-induced $P P A R G$ and CEBPA expression requires Wnt activity, we treated M2-10B4 cells with two specific inhibitors of canonical Wnt signaling: recombinant mouse Dkk1and the 
small molecule XAV939 (Figure 6E). Dkk1 functions as an antagonist of canonical Wnt signaling by binding to lowdensity lipoprotein receptor-related protein (Lrp)5/6 and preventing its interaction with Wnt-Frizzled complexes. ${ }^{51}$ In contrast, XAV939 antagonizes Wnt signaling by stabilizing Axin, an inhibitory Wnt pathway component. ${ }^{52}$ By itself, each Wnt inhibitor increased expression of Pparg and Cebpa when added BMP2 alone. Importantly, NELL-1 suppression of BMP2-induced Pparg or Cebpa expression was largely reversed by Wnt signaling inhibition.

To determine whether Wnt signaling is required for NELL1 augmentation of BMP2-mediated osteogenesis, we added DKK1 to NELL-1+BMP2-treated M2-10B4 cells. DKK1 eliminated the synergistic increase in Runx2 expression induced by NELL-1 addition to BMP2 (Figure 6F). M2-10B4 cells were also transduced with a lentiviral vector containing the Runx2 P1 promoter driving Gfp expression. Treatment of the transduced cells with BMP2 or BMP2+NELL-1 increased Runx2 P1-driven Gfp expression. Moreover, when XAV939 was added, significant inhibition of Runx2 P1 expression was found in NELL-1+BMP2 co-treated cells (Figure 6F). Collectively, these data indicate that NELL-1 regulation of Runx2, PPAR $\gamma$, and $\mathrm{C} / \mathrm{EBP} \alpha$, key transcription factors induced by BMP2 that dictate osteogenic and adipogenic lineage specification, is dependent on intact canonical Wnt signaling.

\section{Discussion}

In this study, we identified NELL-1 as a novel Wnt regulator that can suppress adipogenesis and promote osteogenesis in the context of the high BMP2 doses used clinically. We also demonstrated the ready feasibility of combining NELL-1 with BMP2 to significantly improve the clinical safety and efficacy of BMP2-based bone regeneration.

\section{Proposed Molecular Mechanisms of NELL-1 and BMP2 Effects on Osteogenesis}

The ability of NELL-1 to improve BMP2-induced bone quality can be explained in terms of their mechanistic effects on the master osteogenic and adipogenic regulators Runx2 and $\operatorname{PPAR} \gamma$, respectively. BMP2 induces osteogenic differentiation of mesenchymal progenitor cells by activating Runx2 expression through the action of the Smad family of transcription factors. ${ }^{53}$ This agrees with the well-known ability of BMP2 to induce ectopic and orthotopic bone. ${ }^{54}$ However, high-dose BMP2 also activates PPAR $\gamma$ and $\mathrm{C} / \mathrm{EBP} \alpha$ via Smad signaling ${ }^{55,56}$ and promotes adipogenesis in vitro and in vivo. ${ }^{12,57}$ Importantly, increased PPAR $\gamma$ expression antagonizes Runx2, which in turn inhibits the osteogenic differentiation of mesenchymal progenitor cells, resulting in inconsistent bone formation. ${ }^{31,57,58}$

NELL-1 can function as a downstream mediator of Runx 2 because $N E L L 1$ expression is directly regulated by
Runx2 binding to its promoter region ${ }^{59}$ and Nelll overexpression can partially rescue Runx 2 haploinsufficiency. ${ }^{8}$ In addition, NELL-1 regulates Runx 2 bioactivity by enhancing its phosphorylation. ${ }^{9}$ Co-immunoprecipitation and surface plasmon resonance experiments indicate that NELL-1 does not physically interact with BMP2 (data not shown), and we and others have established that NELL-1 does not participate in the Smad1/5/8 pathways (Supplemental Figure S2B), ${ }^{9}$ suggesting that NELL-1 activates Runx2 via a mechanism independent of the BMP/ Smad pathways.

In the present study, we describe NELL-1 stimulation of Runx 2 expression and activity via canonical Wnt signaling, which is essential for differentiation of progenitor cells into osteoblasts and normal fetal bone development. ${ }^{60,61}$ Endogenous Wnt signaling is also increased in areas of bone healing, and Wnt-filled liposomes can accelerate bone healing. ${ }^{29}$ In osteoblast precursor cells, canonical Wnt signaling directly stimulates the Runx2 P1 promoter to drive osteoblast differentiation. ${ }^{60}$ Because we showed that NELL1 significantly increased the nuclear accumulation of $\beta$ catenin, it is possible that Runx2 expression may be likewise stimulated to induce osteoblastogenesis. Thus, NELL-1 is not only regulated by Runx 2 and acts as its downstream mediator, but NELL-1 may also regulate Runx2 via canonical Wnt signaling. In addition to transcriptional regulation by BMP2, Runx2 physically interacts with Smad proteins to form active transcriptional complexes for osteogenic gene expression, resulting in the synergy between Runx2 and BMP2. ${ }^{62,63}$ Therefore, we hypothesize that NELL-1 may augment BMP2/Smad osteogenesis by stimulating canonical Wnt signaling and promoting Runx2.

\section{Proposed Molecular Mechanisms of NELL-1 and BMP2 Effects on Adipogenesis}

Besides up-regulating osteogenesis, canonical Wnt signaling is widely reported to inhibit adipogenesis in diverse cell types. ${ }^{64,65}$ NELL-1 reduction of PPAR $\gamma$ expression was blocked by canonical Wnt inhibitors, indicating that NELL-1 down-regulation of adipogenesis was dependent on intact Wnt signaling. It was recently reported that BMP2 represses Wnt signaling during bone repair in a 1 -mm in vivo monocortical trephine defect model. ${ }^{66}$ In contrast, our data show lack of BMP2 induction, rather than repression per se, of canonical Wnt signaling. This discrepancy may be due to differences in defect size (ie, 6mm full-thickness FSD versus 1-mm monocortical trephine defect) and origin of bone-forming progenitor cells (ie, bone marrow, periosteum, or surrounding soft tissues). Irrespectively, the up-regulation of Wnt by NELL-1 can explain the ability of NELL-1+BMP2 cotreatment to increase osteogenesis while simultaneously decreasing adipogenesis. Collectively, NELL-1 promotes BMP2 osteogenesis by both up-regulating Runx2 and down-regulating PPAR $\gamma$ via canonical Wnt signaling. 

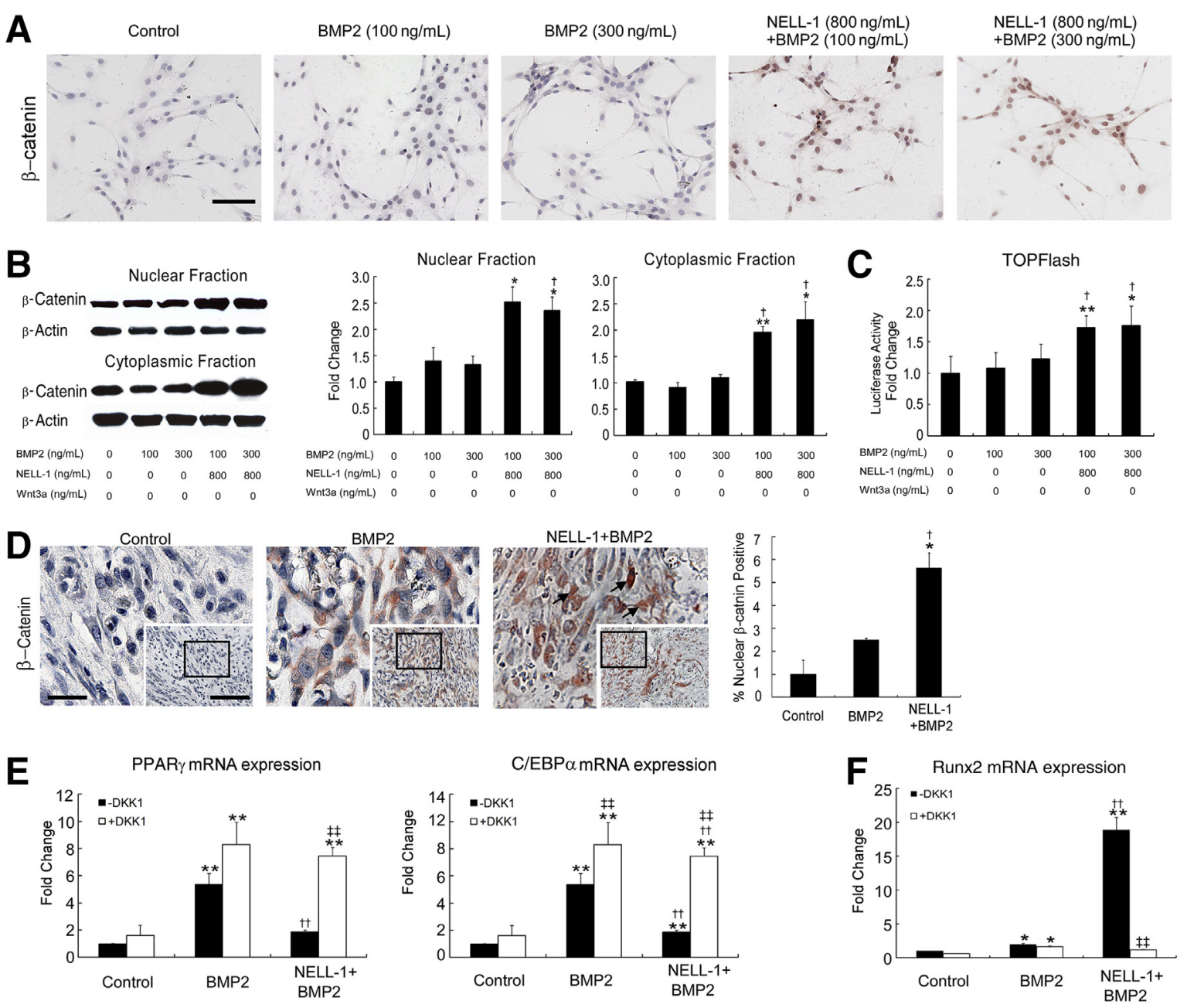

PPARy mRNA expression
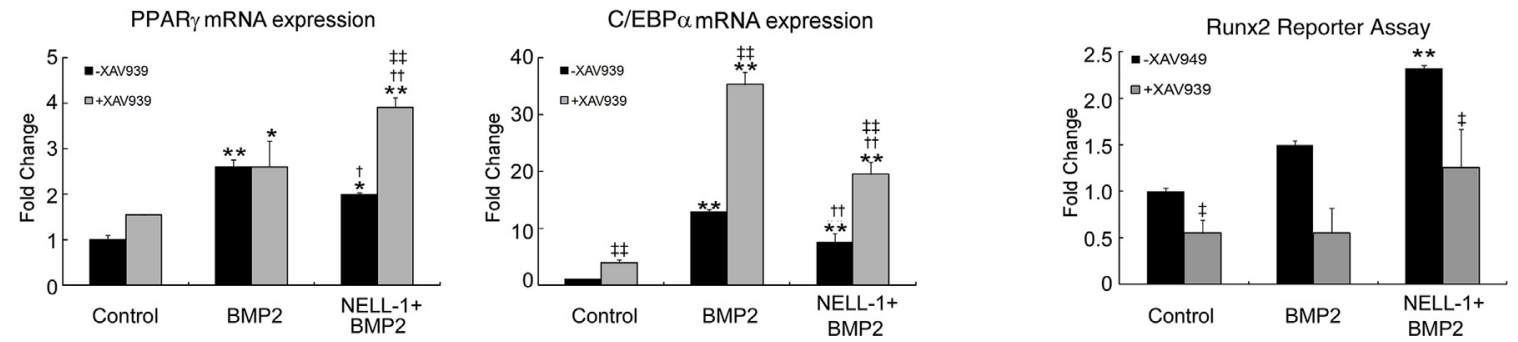

Figure 6 NEL-like molecule-1 (NELL-1) induces canonical Wnt pathway activity in vivo and in vitro. A: M2-10B4 cells were treated with indicated doses of bone morphogenetic protein 2 (BMP2) or BMP2+NELL-1 in RPMI 1640+1\% fetal bovine serum for 2 hours and stained for active $\beta$-catenin. Recombinant Wnt-3a $(100 \mathrm{ng} / \mathrm{mL})$ was used as a positive control. B: Western blot analysis of nuclear and cytoplasmic fractions of $\beta$-catenin 2 hours after treatment under the same conditions as $\mathbf{A}$. Quantitation of nuclear and cytoplasmic $\beta$-catenin shown in graphs to the middle and right. C: M2-10B4 cells were transfected with Super $(16 \times)$ TOPFlash and Renilla luciferase plasmids. Cells were treated with indicated doses of BMP2 or BMP2+NELL-1 for 48 hours. The luciferase activity was normalized to control. D: Immunohistochemical analysis for $\beta$-catenin expression in BMP2 or BMP2+NELL-1 treated samples of femoral segmental defect (within the scaffold implant) at 2 weeks after surgery. BMP2 dose, $600 \mu \mathrm{g} / \mathrm{mL}$; NELL-1 dose, $600 \mu \mathrm{g} / \mathrm{mL}$. Arrowheads highlight positive nuclear staining for $\beta$-catenin. Quantitation of $\beta$-catenin staining is show in graph to the right. Insets and boxed areas indicate areas of magnification. E: Intact canonical Wnt signaling is required for anti-adipogenic and pro-osteogenic effects of NELL-1. M2-10B4 cells were seeded at the density of $1 \times 10^{5}$ cells per well in 24-well plates for 24 hours and treated with phosphate-buffered saline, $300 \mathrm{ng} / \mathrm{mL} \mathrm{BMP2,} \mathrm{or} 300 \mathrm{ng} / \mathrm{mL}$ BMP2 +800 $\mathrm{ng} / \mathrm{mL}$ NELL-1 under adipogenic differentiation conditions with or without $100 \mathrm{ng} / \mathrm{mL}$ Dickkopf-related protein 1 (DKK1) or with or without $1 \mu \mathrm{mol} / \mathrm{L}$ XAV939 for 3 days. Peroxisome proliferator-activated receptor $\gamma$ (PPAR $\gamma$ ) and CCAAT enhancer-binding protein $\alpha(C / E B P \alpha)$ expression was measured by realtime PCR. F, top graph: M2-10B4 cells were seeded at the density of $1 \times 10^{5}$ cells per well in 24-well plates for 24 hours and treated with PBS, $300 \mathrm{ng} / \mathrm{mL}$ $\mathrm{BMP} 2$, or $300 \mathrm{ng} / \mathrm{mL}$ BMP2 $+800 \mathrm{ng} / \mathrm{mL}$ NELL-1 under osteogenic differentiation conditions with or without DKK1 for 3 days. Runx2 expression was measured by real-time PCR. Bottom graph: M2-10B4 cells were transduced with Runx2-enhanced green fluorescent protein reporter lentivirus and treated with PBS, $300 \mathrm{ng} / \mathrm{mL}$ BMP2, or $300 \mathrm{ng} / \mathrm{mL}$ BMP2 $+800 \mathrm{ng} / \mathrm{mL}$ NELL-1 with or without $1 \mu \mathrm{mol} / \mathrm{L}$ XAV939 24 hours after transduction. Runx2 reporter assay was performed on transduced cells after 3 days. All fold changes are reported relative to control group. Data are expressed as means \pm SD. ${ }^{*} P<0.05$, ${ }^{*}{ }^{*} P<0.01$ versus control group; ${ }^{\dagger} P<0.05,{ }^{\dagger \dagger} P<0.01$ versus same dose of BMP2; ${ }^{\ddagger} P<0.05,{ }^{\ddagger \ddagger} P<0.01$ versus no inhibitor treatment. $n=3$ (A, $\mathbf{B}, \mathbf{D}$, and $\mathbf{F}), n=4(\mathbf{C})$. Scale bars $=0.1 \mathrm{~mm}(\mathbf{A} ; \mathbf{D}$, insets); $0.04 \mathrm{~mm}$ (D, boxed area). 
Previously we identified NELL- 1 -integrin- $\beta_{1}$ binding as essential for the NELL-1-mediated activation of Wnt signaling. ${ }^{67}$ In this study, we showed that Dkk1 blocked NELL-1 regulation of BMP2-induced osteogenesis and adipogenesis. Because DKK1 antagonizes canonical Wnt signaling by binding to LRP5/6, preventing its interaction with the Wnt-Frizzled complex, ${ }^{51}$ our data suggest that NELL-1 stimulates canonical Wnt by extracellular mechanisms. The small molecule XAV939, which blocks Wnt signaling by intracellular mechanisms, also abrogated the canonical Wnt response to NELL-1, further verifying the function of NELL-1 in this pathway. Our ongoing study of the mechanisms of NELL-1 activation of Wnt signaling, via integrin- $\beta_{1}$ or other cell surface receptors, will greatly improve our mechanistic understanding of NELL-1 functions.

\section{Cellular Effects of NELL-1 and BMP2 in Femoral Segmental Defect Healing}

Controlling the proper differentiation of local progenitor cells in the defect space is a highly regulated process crucial for normal bone development, maintenance, and healing after injury. ${ }^{68}$ At the cellular level, BMP2 may expand the pool of mesenchymal progenitors by inducing local cell proliferation, ${ }^{69}$ reducing apoptosis of local cells, ${ }^{70}$ or chemotactically recruiting mesenchymal progenitors from the bone marrow or neighboring compartments such as the periosteum and the surrounding muscle and soft tissues. ${ }^{71}$ These mechanisms all increase the number of cells at the defect site and may contribute to the reactive tissue zone induced by clinically relevant, high-dose BMP2 ${ }^{12}$ (Figure 1). Indeed, we found increased proliferation and decreased apoptosis on BMP2 treatment (Supplemental Figure S3), correlating with the increased cellularity induced by BMP2 (Figure 3). Another interesting aspect is the precise cellular constituent that was responsive to NELL-1 and BMP2 in our model. A femoral bone defect environment will expose multiple, distinct cell types to exogenous BMP2 and NELL-1 protein, including BMSCs, endosteal/periosteal progenitor cells, and cortical osteoblasts. Prior studies from our research group have confirmed that multiple cell types are NELL-1 responsive. For example, NELL-1 induction of osteogenesis is best studied in BMSCs ${ }^{39}$ but also has been reported in committed osteoblasts ${ }^{67}$ adipose-derived stem cells, ${ }^{72}$ and perivascular stem cells. ${ }^{73,74}$ Although complex, Understanding the cellspecific responses to NELL-1 and BMP2 treatment may allow for future refinements in protein-based methods of tissue engineering.

Here, NELL-1 alone, delivered from a synthetic PLGA carrier, resulted in limited osteogenesis at the defect margins (Supplemental Figure S1), a location adjacent to the periosteum and bone marrow, which are sources of BMPs and BMSCs. ${ }^{75,76}$ In contrast, we have shown that NELL-1 treatment alone can induce complete defect healing using a demineralized bone matrix carrier, which contains residual BMPs. ${ }^{37,77}$ Finally, using a femoral onlay model, ${ }^{12}$ we found that NELL-1 does not mediate inflammatory cell infiltration, in contrast to BMP2 ${ }^{78}$ Based on these observations, we believe that NELL-1 is not directly chemotactic, but instead promotes a more directed lineage specification of BMP2induced or recruited progenitors toward osteogenesis, while at the same time inhibiting adipogenic lineage commitment. Indeed, we observed reduced cellularity (Supplemental Figure S3) and adipogenesis (Figures 2 and 3) with NELL1+BMP2 cotreatment compared with BMP2 treatment alone. Just as BMPs have differing effects depending on cell subpopulation, ${ }^{66}$ an important future direction will be to identify the precise cell populations targeted by NELL-1 in vivo to further improve its osteoinductive potential.

\section{Potential Applications for NELL-1 in the Clinic}

Clinically, osteoinduction in humans requires high-dose BMP2, which elicits significant adverse effects (http://www. fda.gov/MedicalDevices/Safety/AlertsandNotices/PublicHealth Notifications/ucm062000.htm). ${ }^{22-25}$ The BMP2 doses used in this study were based on those used clinically ${ }^{17}$; lesser BMP2 doses are not osteoinductive in humans. ${ }^{79}$ Based on our previous data, ${ }^{12}$ low BMP2 doses $(<150 \mu \mathrm{g} / \mathrm{mL})$ induce osteogenesis and bone healing in rat FSDs but do not elicit adipogenic effects. We did find that treatment groups receiving lesser doses of BMP2 supplemented with NELL-1 achieved radiographic scores greater than those from groups receiving BMP2 alone (data not shown). Because NELL-1 can improve bone formation even if lesser BMP2 doses are used, an interesting future direction would be to test whether the combination of NELL-1 with BMP2 can reduce the currently required clinical dose of BMP2, to potentially reduce the adverse effects of high-dose BMP2.

Because NELL-1 alone significantly inhibits PPAR $\gamma$ expression (Figure 4), it may also have an inherent suppressive effect on adipogenesis independent of BMP2-induced adipogenesis. ${ }^{80}$ Because canonical Wnt inhibitors did not completely eliminate the antiadipogenic effect of NELL-1 on BMP2-induced adipogenesis, we hypothesize that other pathways, such as Hedgehog signaling, may be involved in adipogenic regulation. ${ }^{81}$ The ability of NELL-1 to activate Wnt signaling suggests potential utility in conditions such as osteoporosis, in which the balance between osteogenesis versus adipogenesis and the balance between bone deposition versus resorption are perturbed to favor bone loss. ${ }^{31,82-85}$ In fact, in recognition of the importance of Wnt signaling in bone disease in humans, antibodies against two endogenous Wnt pathway inhibitors, sclerostin and DKK-1, are currently in Phase 2 clinical trials in osteoporosis. ${ }^{85}$ Additionally, ligand activators of PPAR $\gamma$, such as the antidiabetic drug class thiazolidinediones, induce adipogenesis and osteoclastogenesis, ${ }^{86}$ whereas $P P A R G$ haploinsufficiency increases osteoblastogenesis over adipogenesis. ${ }^{87}$ Meanwhile, Wnt signaling promotion can decrease osteoclastogenesis. ${ }^{88}$ Thus, NELL-1 stimulation of Wnt signaling may not only repress $\operatorname{PPAR} \gamma$ to increase osteoblastogenesis but also reduce 
osteoclastogenesis and associated bone loss. ${ }^{24,89}$ In support of this concept, mice homozygous for Nell1 deficiency exhibit reduced expression of the osteoclastogenesis inhibitor osteoprotegerin, ${ }^{6}$ and the heterozygous Nell1-deficient mice that survive to adulthood manifest an osteoporotic phenotype. ${ }^{39}$ Interestingly, BMP2 and Wnt signaling synergistically increase osteoprotegerin expression, ${ }^{90}$ and ongoing studies will determine whether BMP2+NELL-1 can similarly induce osteoprotegerin and/or inhibit osteoclastogenesis.

\section{Conclusions}

Taken together, the findings from our previous ${ }^{12-14,26,37}$ and present studies demonstrate a strong mechanistic rationale for combining NELL-1 with BMP2 to significantly improve the safety and efficacy of the currently clinically available bone-regeneration capabilities. The combination treatment of NELL-1 with BMP2 may be particularly valuable in clinical scenarios in which bone regeneration is impaired, such as in patients undergoing corticosteroid treatment or having osteoporosis. In addition, the novel ability of NELL-1 to stimulate Wnt signaling and to repress adipogenesis may highlight new treatment approaches for osteoporotic bone loss that aim to both increase osteoblastogenesis and decrease osteoclastogenesis.

\section{Acknowledgments}

We thank the Translational Pathology Core Laboratory and the Division of Surgical Pathology (UCLA Department of Pathology and Laboratory Medicine) for technical assistance with histological examination and Statistical Consulting Services (UCLA Academic Technology Services).

J.S., X.Z., S.P., K.T., and C.S. designed the study; J.S., R.K.S., X.Z., S.P., and J.N.Z. performed experiments; J.S., R.K.S., X.Z., J.N.Z., K.K., and M.L. collected data; J.S., A.W.J., K.K., A.N., and K.S.L. analyzed data; J.S., R.K.S., X.Z., A.W.J., S.T., K.T., and C.S. interpreted data; J.S. and R.K.S. wrote the manuscript; and J.S., R.K.S., X.Z., J.N.Z., A.W.J., K.S.L., and S.T. revised the manuscript. K.T. and C.S. take responsibility for the integrity of the data analysis.

\section{Supplemental Data}

Supplemental material for this article can be found at http://dx.doi.org/10.1016/j.ajpath.2015.10.011.

\section{References}

1. Ting K, Vastardis H, Mulliken JB, Soo C, Tieu A, Do H, Kwong E, Bertolami CN, Kawamoto H, Kuroda S, Longaker MT: Human NELL-1 expressed in unilateral coronal synostosis. J Bone Miner Res 1999, 14:80-89
2. Kuroda S, Oyasu M, Kawakami M, Kanayama N, Tanizawa K, Saito N, Abe T, Matsuhashi S, Ting K: Biochemical characterization and expression analysis of neural thrombospondin-1-like proteins NELL1 and NELL2. Biochem Biophys Res Commun 1999, 265: 79-86

3. Zhang X, Kuroda S, Carpenter D, Nishimura I, Soo C, Moats R, Iida K, Wisner E, Hu F-Y, Miao S, Beanes S, Dang C, Vastardis H, Longaker M, Tanizawa K, Kanayama N, Saito N, Ting K: Craniosynostosis in transgenic mice overexpressing Nell-1. J Clin Invest 2002, 110:861-870

4. Siu RK, Zhang X, Ko T, Wu BM, Ting K, Culiat CT, Soo C: Nell-1 deficient mice exhibit abnormal structure in spinal and long bones. Presented at the 31st Annual Meeting of the American Society for Bone and Mineral Research. 2009 September 1114, Denver, CO

5. Zhang X, Ting K, Pathmanathan D, Ko T, Chen W, Chen F, Lee H, James AW, Siu RK, Shen J, Culiat CT, Soo C: Calvarial cleidocraniodysplasia-like defects in ENU-induced Nell-1 deficient mice. J Craniofac Surg 2012, 23:61-66

6. Desai J, Shannon ME, Johnson MD, Ruff DW, Hughes LA, Kerley MK, Carpenter DA, Johnson DK, Rinchik EM, Culiat CT: Nell1-deficient mice have reduced expression of extracellular matrix proteins causing cranial and vertebral defects. Hum Mol Genet 2006, 15:1329-1341

7. Komori T: Regulation of bone development and maintenance by Runx2. Front Biosci 2008, 13:898-903

8. Zhang X, Ting K, Bessette CM, Culiat CT, Sung SJ, Lee H, Chen F, Shen J, Wang JJ, Kuroda S, Soo C: Nell-1, a key functional mediator of Runx2, partially rescues calvarial defects in Runx2(+/-) mice. J Bone Miner Res 2011, 26:777-791

9. Bokui N, Otani T, Igarashi K, Kaku J, Oda M, Nagaoka T, Seno M, Tatematsu K, Okajima T, Matsuzaki T, Ting K, Tanizawa K, Kuroda S: Involvement of MAPK signaling molecules and Runx 2 in the NELL1induced osteoblastic differentiation. FEBS Lett 2008, 582:365-371

10. Zou X, Shen J, Chen F, Ting K, Zheng Z, Pang S, Zara JN, Adams JS, Soo C, Zhang X: NELL-1 binds to APR3 affecting human osteoblast proliferation and differentiation. FEBS Lett 2011, 585: 2410-2418

11. Aghaloo T, Jiang X, Soo C, Zhang Z, Zhang X, Hu J, Pan H, Hsu T, Wu B, Ting K, Zhang X: A study of the role of Nell-1 gene modified goat bone marrow stromal cells in promoting new bone formation. Mol Ther 2007, 15:1872-1880

12. Zara JN, Siu RK, Zhang X, Shen J, Ngo R, Lee M, Li W, Chiang M, Chung J, Kwak J, Wu BM, Ting K, Soo C: High doses of bone morphogenetic protein 2 induce structurally abnormal bone and inflammation in vivo. Tissue Eng Part A 2011, 17:1389-1399

13. Lu SS, Zhang X, Soo C, Hsu T, Napoli A, Aghaloo T, Wu BM, Tsou P, Ting K, Wang JC: The osteoinductive properties of Nell-1 in a rat spinal fusion model. Spine J 2007, 7:50-60

14. Li W, Lee M, Whang J, Siu RK, Zhang X, Liu C, Wu BM, Wang JC, Ting K, Soo C: Delivery of lyophilized Nell-1 in a rat spinal fusion model. Tissue Eng Part A 2010, 16:2861-2870

15. Siu RK, Lu SS, Li W, Whang J, McNeill G, Zhang X, Wu BM, Turner AS, Seim HB, Hoang P, Wang JC, Gertzman AA, Ting K, Soo C: Nell-1 protein promotes bone formation in a sheep spinal fusion model. Tissue Eng Part A 2011, 17:1123-1135

16. Khan SN, Lane JM: The use of recombinant human bone morphogenetic protein-2 (rhBMP-2) in orthopaedic applications. Expert Opin Biol Ther 2004, 4:741-748

17. Boden SD, Zdeblick TA, Sandhu HS, Heim SE: The use of rhBMP-2 in interbody fusion cages. Definitive evidence of osteoinduction in humans: a preliminary report. Spine (Phila Pa 1976) 2000, 25: $376-381$

18. Walker DH, Wright NM: Bone morphogenetic proteins and spinal fusion. Neurosurg Focus 2002, 13:1-13

19. Boden SD, Kang J, Sandhu H, Heller JG: Use of recombinant human bone morphogenetic protein-2 to achieve posterolateral lumbar spine 
fusion in humans: a prospective, randomized clinical pilot trial: 2002 Volvo Award in clinical studies. Spine (Phila Pa 1976) 2002, 27: 2662-2673

20. US Food and Drug Administration: InFUSE Bone Graft/LTCAGE Lumbar Tapered Fusion Device. Summary of safety and effective data premarket approval application P000058. Available at http://www.fda.gov/MedicalDevices/Productsand MedicalProcedures/DeviceApprovalsandClearances/Recently-Approved Devices/ucm083423.htm

21. McKay B, Sandhu HS: Use of recombinant human bone morphogenetic protein-2 in spinal fusion applications. Spine 2002, 27 : S66-S85

22. Shields LB, Raque GH, Glassman SD, Campbell M, Vitaz T, Harpring J, Shields CB: Adverse effects associated with high-dose recombinant human bone morphogenetic protein-2 use in anterior cervical spine fusion. Spine 2006, 31:542-547

23. Boraiah S, Paul O, Hawkes D, Wickham M, Lorich DG: Complications of recombinant human BMP-2 for treating complex tibial plateau fractures: a preliminary report. Clin Orthop Relat Res 2009, 467:3257-3262

24. Irie K, Alpaslan C, Takahashi K, Kondo Y, Izumi N, Sakakura Y, Tsuruga E, Nakajima T, Ejiri S, Ozawa H, Yajima T: Osteoclast differentiation in ectopic bone formation induced by recombinant human bone morphogenetic protein 2 (rhBMP-2). J Bone Miner Metab 2003, 21:363-369

25. Vaidya R, Weir R, Sethi A, Meisterling S, Hakeos W, Wybo CD: Interbody fusion with allograft and rhBMP-2 leads to consistent fusion but early subsidence. J Bone Joint Surg Br 2007, 89: $342-345$

26. Cowan CM, Jiang X, Hsu T, Soo C, Zhang B, Wang JZ, Kuroda S, Wu B, Zhang Z, Zhang X, Ting K: Synergistic effects of Nell-1 and BMP-2 on the osteogenic differentiation of myoblasts. J Bone Miner Res 2007, 22:918-930

27. Sciadini MF, Johnson KD: Evaluation of recombinant human bone morphogenetic protein-2 as a bone-graft substitute in a canine segmental defect model. J Orthop Res 2000, 18:289-302

28. Mannion RJ, Nowitzke AM, Wood MJ: Promoting fusion in minimally invasive lumbar interbody stabilization with low-dose bone morphogenic protein-2-but what is the cost? Spine J 2011, 11: $527-533$

29. Minear S, Leucht P, Jiang J, Liu B, Zeng A, Fuerer C, Nusse R, Helms JA: Wnt proteins promote bone regeneration. Sci Transl Med 2010, 2:29ra30

30. Krause U, Harris S, Green A, Ylostalo J, Zeitouni S, Lee N, Gregory CA: Pharmaceutical modulation of canonical Wnt signaling in multipotent stromal cells for improved osteoinductive therapy. Proc Natl Acad Sci U S A 2010, 107:4147-4152

31. Takada I, Kouzmenko AP, Kato S: Wnt and PPARgamma signaling in osteoblastogenesis and adipogenesis. Nat Rev Rheumatol 2009, 5: 442-447

32. Leucht P, Minear S, Ten Berge D, Nusse R, Helms JA: Translating insights from development into regenerative medicine: the function of Wnts in bone biology. Semin Cell Dev Biol 2008, 19: 434-443

33. Li HX, Luo X, Liu RX, Yang YJ, Yang GS: Roles of Wnt/betacatenin signaling in adipogenic differentiation potential of adipose-derived mesenchymal stem cells. Mol Cell Endocrinol 2008, 291:116-124

34. Nusse R, Gordon MD: Wnt signaling: multiple pathways, multiple receptors, and multiple transcription factors. J Biol Chem 2006, 281 : 22429-22433

35. Yu HM, Jerchow B, Sheu TJ, Liu B, Costantini F, Puzas JE, Birchmeier W, Hsu W: The role of Axin2 in calvarial morphogenesis and craniosynostosis. Development 2005, 132:1995-2005

36. Chou YF, Huang W, Dunn JC, Miller TA, Wu BM: The effect of biomimetic apatite structure on osteoblast viability, proliferation, and gene expression. Biomaterials 2005, 26:285-295
37. Li W, Zara JN, Siu RK, Lee M, Aghaloo T, Zhang X, Wu BM, Gertzman AA, Ting K, Soo C: Nell-1 enhances bone regeneration in a rat critical-sized femoral segmental defect model. Plast Reconstr Surg 2011, 127:580-587

38. Bouxsein ML, Boyd SK, Christiansen BA, Guldberg RE, Jepsen KJ, Muller R: Guidelines for assessment of bone microstructure in rodents using micro-computed tomography. J Bone Miner Res 2010, $25: 1468-1486$

39. James AW, Shen J, Zhang X, Asatrian G, Goyal R, Kwak JH, Jiang L, Bengs B, Culiat CT, Turner AS, Seim HB 3rd, Wu BM, Lyons K, Adams JS, Ting K, Soo C: NELL-1 in the treatment of osteoporotic bone loss. Nat Commun 2015, 6:7362

40. Xu Y, Hammerick KE, James AW, Carre AL, Leucht P, Giaccia AJ, Longaker MT: Inhibition of histone deacetylase activity in reduced oxygen environment enhances the osteogenesis of mouse adipose-derived stromal cells. Tissue Eng Part A 2009, 15:3697-3707

41. Parfitt AM, Drezner MK, Glorieux FH, Kanis JA, Malluche H, Meunier PJ, Ott SM, Recker RR: Bone histomorphometry: standardization of nomenclature, symbols, and units. Report of the ASBMR Histomorphometry Nomenclature Committee. J Bone Miner Res 1987, 2:595-610

42. Sutherland HJ, Eaves CJ, Lansdorp PM, Thacker JD, Hogge DE: Differential regulation of primitive human hematopoietic cells in long-term cultures maintained on genetically engineered murine stromal cells. Blood 1991, 78:666-672

43. Kha HT, Basseri B, Shouhed D, Richardson J, Tetradis S, Hahn TJ, Parhami F: Oxysterols regulate differentiation of mesenchymal stem cells: pro-bone and anti-fat. J Bone Miner Res 2004, 19:830-840

44. Marion NW, Mao JJ: Mesenchymal stem cells and tissue engineering. Methods Enzymol 2006, 420:339-361

45. Chen W, Zhang X, Siu RK, Chen F, Shen J, Zara JN, Culiat CT, Tetradis S, Ting K, Soo C: Nfatc2 is a primary response gene of Nell1 regulating chondrogenesis in ATDC5 cells. J Bone Miner Res 2011, 26:1230-1241

46. Barry SC, Harder B, Brzezinski M, Flint LY, Seppen J, Osborne WR: Lentivirus vectors encoding both central polypurine tract and posttranscriptional regulatory element provide enhanced transduction and transgene expression. Hum Gene Ther 2001, 12:1103-1108

47. Pang S, Kang MK, Kung S, Yu D, Lee A, Poon B, Chen IS, Lindemann B, Park NH: Anticancer effect of a lentiviral vector capable of expressing HIV-1 Vpr. Clin Cancer Res 2001, 7: $3567-3573$

48. Tontonoz P, Hu E, Spiegelman BM: Regulation of adipocyte gene expression and differentiation by peroxisome proliferator activated receptor gamma. Curr Opin Genet Dev 1995, 5:571-576

49. Darlington GJ, Ross SE, MacDougald OA: The role of C/EBP genes in adipocyte differentiation. J Biol Chem 1998, 273: 30057-30060

50. Osyczka AM, Diefenderfer DL, Bhargave G, Leboy PS: Different effects of BMP-2 on marrow stromal cells from human and rat bone. Cells Tissues Organs 2004, 176:109-119

51. Mao B, Wu W, Li Y, Hoppe D, Stannek P, Glinka A, Niehrs C: LDLreceptor-related protein 6 is a receptor for Dickkopf proteins. Nature 2001, 411:321-325

52. Huang SM, Mishina YM, Liu S, Cheung A, Stegmeier F, Michaud GA, et al: Tankyrase inhibition stabilizes axin and antagonizes Wnt signalling. Nature 2009, 461:614-620

53. Miyazono K, Maeda S, Imamura T: BMP receptor signaling: transcriptional targets, regulation of signals, and signaling cross-talk. Cytokine Growth Factor Rev 2005, 16:251-263

54. Wang R, Zou Y, Yuan Z, Wang Y, Chen Y, Mao Y, Zhu ZA, Li H, Tang X, Lu J, Yi J: Autografts and xenografts of skin fibroblasts delivering BMP-2 effectively promote orthotopic and ectopic osteogenesis. Anat Rec (Hoboken) 2009, 292:777-786

55. Fux C, Mitta B, Kramer BP, Fussenegger M: Dual-regulated expression of C/EBP-alpha and BMP-2 enables differential 
differentiation of $\mathrm{C} 2 \mathrm{C} 12$ cells into adipocytes and osteoblasts. Nucleic Acids Res 2004, 32:e1

56. Jin W, Takagi T, Kanesashi SN, Kurahashi T, Nomura T, Harada J, Ishii S: Schnurri-2 controls BMP-dependent adipogenesis via interaction with Smad proteins. Dev Cell 2006, 10:461-471

57. Kang Q, Song WX, Luo Q, Tang N, Luo J, Luo X, Chen J, Bi Y, He BC, Park JK, Jiang W, Tang Y, Huang J, Su Y, Zhu GH, He Y, Yin H, Hu Z, Wang Y, Chen L, Zuo GW, Pan X, Shen J, Vokes T, Reid RR, Haydon RC, Luu HH, He TC: A comprehensive analysis of the dual roles of BMPs in regulating adipogenic and osteogenic differentiation of mesenchymal progenitor cells. Stem Cells Dev 2009, 18:545-559

58. Moerman EJ, Teng K, Lipschitz DA, Lecka-Czernik B: Aging activates adipogenic and suppresses osteogenic programs in mesenchymal marrow stroma/stem cells: the role of PPAR-gamma2 transcription factor and TGF-beta/BMP signaling pathways. Aging Cell 2004, 3:379-389

59. Truong $T$, Zhang X, Pathmanathan D, Soo C, Ting K: Craniosynostosis-associated gene Nell-1 is regulated by Runx2. J Bone Miner Res 2007, 22:7-18

60. Gaur T, Lengner CJ, Hovhannisyan H, Bhat RA, Bodine PV, Komm BS, Javed A, van Wijnen AJ, Stein JL, Stein GS, Lian JB: Canonical WNT signaling promotes osteogenesis by directly stimulating Runx2 gene expression. J Biol Chem 2005, 280:33132-33140

61. Brault V, Moore R, Kutsch S, Ishibashi M, Rowitch DH, McMahon AP, Sommer L, Boussadia O, Kemler R: Inactivation of the beta-catenin gene by Wnt1-Cre-mediated deletion results in dramatic brain malformation and failure of craniofacial development. Development 2001, 128:1253-1264

62. Afzal F, Pratap J, Ito K, Ito Y, Stein JL, van Wijnen AJ, Stein GS, Lian JB, Javed A: Smad function and intranuclear targeting share a Runx2 motif required for osteogenic lineage induction and BMP-2 responsive transcription. J Cell Physiol 2005, 204:63-72

63. Zhang YW, Yasui N, Ito K, Huang G, Fujii M, Hanai J, Nogami H, Ochi T, Miyazono K, Ito Y: A RUNX2/PEBP2alpha A/CBFA1 mutation displaying impaired transactivation and Smad interaction in cleidocranial dysplasia. Proc Natl Acad Sci U S A 2000, 97: 10549-10554

64. Ross SE, Hemati N, Longo KA, Bennett CN, Lucas PC, Erickson RL, MacDougald OA: Inhibition of adipogenesis by Wnt signaling. Science 2000, 289:950-953

65. Zhou S, Eid K, Glowacki J: Cooperation between TGF-beta and Wnt pathways during chondrocyte and adipocyte differentiation of human marrow stromal cells. J Bone Miner Res 2004, 19:463-470

66. Minear S, Leucht P, Miller S, Helms JA: rBMP represses Wnt signaling and influences skeletal progenitor cell fate specification during bone repair. J Bone Miner Res 2010, 25:1196-1207

67. Shen J, James AW, Chung J, Lee K, Zhang JB, Ho S, Lee KS, Kim TM, Niimi T, Kuroda S, Ting K, Soo C: NELL-1 promotes cell adhesion and differentiation via Integrinbeta1. J Cell Biochem 2012, $113: 3620-3628$

68. Tuan RS: Biology of developmental and regenerative skeletogenesis. Clin Orthop Relat Res 2004:S105-S117

69. Fromigue O, Marie PJ, Lomri A: Bone morphogenetic protein-2 and transforming growth factor-beta2 interact to modulate human bone marrow stromal cell proliferation and differentiation. J Cell Biochem 1998, 68:411-426

70. Liu Z, Shen J, Pu K, Katus HA, Ploger F, Tiefenbacher CP, Chen X, Braun T: GDF5 and BMP-2 inhibit apoptosis via activation of BMPR2 and subsequent stabilization of XIAP. Biochim Biophys Acta 2009, 1793:1819-1827

71. Gerstenfeld LC, Cullinane DM, Barnes GL, Graves DT, Einhorn TA: Fracture healing as a post-natal developmental process: molecular, spatial, and temporal aspects of its regulation. J Cell Biochem 2003, $88: 873-884$

72. James AW, Pang S, Askarinam A, Corselli M, Zara JN, Goyal R, Chang L, Pan A, Shen J, Yuan W, Stoker D, Zhang X, Adams JS,
Ting K, Soo C: Additive effects of sonic hedgehog and Nell-1 signaling in osteogenic versus adipogenic differentiation of human adipose-derived stromal cells. Stem Cells Dev 2012, 21:2170-2178

73. Lee S, Zhang X, Shen J, James AW, Chung CG, Hardy R, Li C, Girgius C, Zhang Y, Stoker D, Wang H, Wu BM, Peault B, Ting K, Soo C: Brief report: human perivascular stem cells and Nel-like protein-1 synergistically enhance spinal fusion in osteoporotic rats. Stem Cells 2015, 33:3158-3163

74. Askarinam A, James AW, Zara JN, Goyal R, Corselli M, Pan A, Liang P, Chang L, Rackohn T, Stoker D, Zhang X, Ting K, Peault B, Soo C: Human perivascular stem cells show enhanced osteogenesis and vasculogenesis with Nel-like molecule I protein. Tissue Eng Part A 2013, 19:1386-1397

75. Bostrom MP, Lane JM, Berberian WS, Missri AA, Tomin E, Weiland A, Doty SB, Glaser D, Rosen VM: Immunolocalization and expression of bone morphogenetic proteins 2 and 4 in fracture healing. J Orthop Res 1995, 13:357-367

76. Prockop DJ: Marrow stromal cells as stem cells for nonhematopoietic tissues. Science 1997, 276:71-74

77. Wildemann B, Kadow-Romacker A, Pruss A, Haas NP, Schmidmaier G: Quantification of growth factors in allogenic bone grafts extracted with three different methods. Cell Tissue Bank 2007, 8:107-114

78. Shen J, James AW, Zara JN, Asatrian G, Khadarian K, Zhang JB, Ho S, Kim HJ, Ting K, Soo C: BMP-2-induced inflammation can be suppressed by the osteoinductive growth factor NELL-1. Tissue Eng Part A 2013, 19:2390-2401

79. McKay B: Science-based assessment: accelerating product development of combination medical devices. Presented at the 7th National Materials and Manufacturing Board Roundtable on Biomedical Engineering Materials and Applications. 2003 February 11, Washington, DC

80. James AW, Pan A, Chiang M, Zara JN, Zhang X, Ting K, Soo C: A new function of Nell-1 protein in repressing adipogenic differentiation. Biochem Biophys Res Commun 2011, 411:126-131

81. James AW, Leucht P, Levi B, Carre AL, Xu Y, Helms JA, Longaker MT: Sonic Hedgehog influences the balance of osteogenesis and adipogenesis in mouse adipose-derived stromal cells. Tissue Eng Part A 2010, 16:2605-2616

82. Ettinger MP: Aging bone and osteoporosis: strategies for preventing fractures in the elderly. Arch Intern Med 2003, 163:2237-2246

83. Justesen J, Stenderup K, Eriksen EF, Kassem M: Maintenance of osteoblastic and adipocytic differentiation potential with age and osteoporosis in human marrow stromal cell cultures. Calcif Tissue Int 2002, 71:36-44

84. Turner AS: Animal models of osteoporosis-necessity and limitations. Eur Cell Mater 2001, 1:66-81

85. Rachner TD, Khosla S, Hofbauer LC: Osteoporosis: now and the future. Lancet 2011, 377:1276-1287

86. Wan Y, Chong LW, Evans RM: PPAR-gamma regulates osteoclastogenesis in mice. Nat Med 2007, 13:1496-1503

87. Akune T, Ohba S, Kamekura S, Yamaguchi M, Chung UI, Kubota N, Terauchi Y, Harada Y, Azuma Y, Nakamura K, Kadowaki T, Kawaguchi H: PPARgamma insufficiency enhances osteogenesis through osteoblast formation from bone marrow progenitors. J Clin Invest 2004, 113:846-855

88. Wei W, Zeve D, Suh JM, Wang X, Du Y, Zerwekh JE, Dechow PC, Graff JM, Wan Y: Biphasic and dosage-dependent regulation of osteoclastogenesis by \{beta\}-catenin. Mol Cell Biol 2011, 31:4706-4719

89. Itoh K, Udagawa N, Katagiri T, Iemura S, Ueno N, Yasuda H, Higashio K, Quinn JM, Gillespie MT, Martin TJ, Suda T, Takahashi N: Bone morphogenetic protein 2 stimulates osteoclast differentiation and survival supported by receptor activator of nuclear factor-kappaB ligand. Endocrinology 2001, 142:3656-3662

90. Sato MM, Nakashima A, Nashimoto M, Yawaka Y, Tamura M: Bone morphogenetic protein-2 enhances Wnt/beta-catenin signaling-induced osteoprotegerin expression. Genes Cells 2009, 14:141-153 